\title{
Synthesis, Characterization, and Anticancer Activity of New Metal Complexes Derived from 2-Hydroxy-3- (hydroxyimino)-4-oxopentan-2-ylidene)benzohydrazide
}

\author{
Abdou Saad El-Tabl, ${ }^{1}$ Moshira Mohamed Abd El-Waheed, ${ }^{2}$ \\ Mohammed Ahmed Wahba, ${ }^{3}$ and Nahla Abd El-Halim Abou El-Fadl ${ }^{1}$ \\ ${ }^{1}$ Department of Chemistry, Faculty of Science, Menoufia University, P.O. Box 5744, Shibin Al Kawm, Egypt \\ ${ }^{2}$ Department of Pathology, Faculty of Medicine, Menoufia University, P.O. Box 5744, Shibin Al Kawm, Egypt \\ ${ }^{3}$ Inorganic Chemistry Department, National Research Centre, Dokki, Cairo 12311, Egypt \\ Correspondence should be addressed to Abdou Saad El-Tabl; asaeltabl@yahoo.com
}

Received 2 February 2015; Revised 5 May 2015; Accepted 27 May 2015

Academic Editor: Claudio Pettinari

Copyright ( 2015 Abdou Saad El-Tabl et al. This is an open access article distributed under the Creative Commons Attribution License, which permits unrestricted use, distribution, and reproduction in any medium, provided the original work is properly cited.

\begin{abstract}
Novel metal(II) complexes derived from 2-hydroxy- $\mathrm{N}^{\prime}-((\mathrm{Z})$-3-(hydroxyimino)-4-oxopentan-2-ylidene)benzohydrazide ligand $\left(\mathrm{H}_{2} \mathrm{~L}\right)$ were synthesized and characterized by elemental and thermal analyses (DTA and TGA), IR, UV-VIS, ${ }^{1} \mathrm{H}-\mathrm{NMR}$, ESR and mass spectroscopy, magnetic susceptibilities, and conductivities measurements. The complexes adopt distorted octahedral geometry. The ESR spectra of the solid copper(II) complexes are characteristic to $\mathrm{d}^{9}$ configuration and have an axial symmetry type of a $\mathrm{d}_{\left(x^{2}-y^{2}\right)}$ ground state. The $g$ values confirmed the tetragonal octahedral geometry with a considerably ionic or covalent environment. The cytotoxic activity of the ligand and its metal complexes showed potent cytotoxicity effect against growth of human liver cancer HepG2 cell lines compared to the clinically used Sorafenib (Nexavar).
\end{abstract}

\section{Introduction}

There is a growing interest in oxime-hydrazone and their coordination compounds caused by their biological activity $[1,2]$. Many clinically successful anticancer drugs were either naturally occurring molecules or have been developed from their synthetic analogs. Metal complexes have unique properties enhancing their role as antitumor agents. An important property is the ability of metals to form positively charged ions in an aqueous solution that can bind to negatively charged biological molecules $[3,4]$. The high electron affinity of metal ions can significantly polarize groups that are coordinated to them, leading to the generation of hydrolysis reactions [4]. Furthermore, metal ions also has the ability to coordinate ligands in a three dimensional configuration, thus allowing functionalization of groups that can be tailored to defined molecular targets $[5,6]$. Recently, considerable attention has been drawn to oximes, hydrazones, and their coordinated compounds due to their biological activities as fungicides [7, 8], bactericides [9], analgesic and anti-inflammatory [10], antioxidant [11, 12], antitumor [13-15], and insecticidal [16]. Metal complexes of bis-hydrazone derived from isatin monohydrazone and 2-hydroxy-1-naphthaldehyde have been reported and they demonstrated interesting biological properties [17]. Oxovanadium(IV) complexes derived from 2-thiophene carboxylic acid hydrazide showed a great cytotoxicity towards Artemia salina [18]. Homo- and heteronuclear copper(II) and nickel(II) complexes derived from oxime-type ligands have been also reported; the observed $\mathrm{IC}_{50}$ values indicated that they are potential antioxidant [19]. Cytotoxicity of a series of cobalt(II) complexes of 2 -furaldehyde oximes was compared with copper complexes of furan oximes to determine whether the type of metal is important to the cytotoxicity and mode of action of the complexes. It was shown that varying the type of metal produces differences in both cytotoxicity and mode of action [20]. 


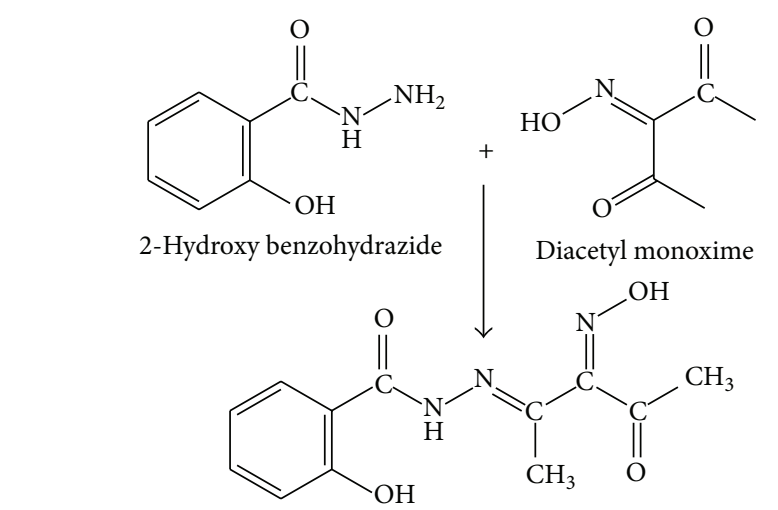

(E)-2-Hydroxy- $\mathrm{N}^{\prime}$-((Z)-3-(hydroxyimino)-4-oxopentan-2-ylidene)benzohydrazide

Ligand $\mathrm{H}_{2} \mathrm{~L}$

Figure 1: Preparation of the ligand $\left[\mathrm{H}_{2} \mathrm{~L}\right]$.

Oxime hydrazones can react with metal(II) salts to produce either mono- or binuclear complexes. The keto hydrazone moiety may coordinate to metals in the ketoamide or deprotonated enolimine form. Compounds containing both oxime and hydrazone groups are typically act as tridentate, mono- or biprotic ligands coordinating through the amide oxygen, imine, and oxime nitrogen atom depending on the reaction conditions [21]. Considerable interest has been attracted to synthesize oxime-hydrazide compounds as important target structures and evaluated their biological activities. These observations have been guiding the development of new compounds that possess varied biological activities. In view of interest and importance of oxime-hydrazide complexes, we reported here synthesis and characterization of new metal complexes derived from 2-hydroxy-N ${ }^{\prime}$-((Z)-3-(hydroxyimino)-4-oxopentan-2ylidene)benzohydrazide. The work was extended to study the anticancer activity of the ligand and its metal complexes against human liver cancer HepG2.

\section{Experimental}

2.1. Instrumentation. All reagents employed for the preparation of the ligand and its complexes were of the analytical grade available and used without further purification. Metal salts and salicylic hydrazide were provided from SIGMAALDRICH company; diacetylmonoxime was prepared by a published method [22]. The purity of all compounds was confirmed by TLC. The ligand and its metal complexes were analyzed for $\mathrm{C}, \mathrm{H}$, and $\mathrm{N}$ at the Microanalytical center, Cairo University, Egypt. Standard analytical methods were used to determine the metal ion content [23]. FT-IR spectra of the ligand and its metal complexes were measured using $\mathrm{KBr}$ discs by a Jasco FT/IR 300E Fourier transform infrared spectrophotometer covering the range $400-4000 \mathrm{~cm}^{-1}$. Electronic spectra in the $200-900 \mathrm{~nm}$ regions were recorded on a Perkin-Elmer 550 spectrophotometer. The thermal analyses (DTA and TGA) were carried out on a Shimadzu DT30 thermal analyzer from room temperature to $800^{\circ} \mathrm{C}$ at a heating rate of $10^{\circ} \mathrm{C} / \mathrm{min}$. Magnetic susceptibilities were measured at $25^{\circ} \mathrm{C}$ by the Gouy method using mercuric
tetrathiocyanatocobaltate(II) as the magnetic susceptibility standard. Diamagnetic corrections were estimated from Pascal's constant [24]. The magnetic moments were calculated from the equation

$$
\mu_{\text {eff. }}=2.84 \sqrt{\chi_{M}^{\text {corr }} \cdot T}
$$

The molar conductance of $10^{-3} \mathrm{M}$ solution of the complexes in DMSO was measured at $25^{\circ} \mathrm{C}$ with a Bibby conductometer type $\mathrm{MCl}$. The resistance measured in ohms and the molar conductivities were calculated according to the equation

$$
\Lambda_{M}=V * K * \frac{g}{M_{w}} * \Omega,
$$

where $\Lambda_{M}=$ molar conductivity $\left(\Omega^{-1} \mathrm{~cm}^{2} \mathrm{~mol}^{-1}\right), V=$ volume of the complex solution $(\mathrm{mL}), K=$ cell constant $\left(0.92 / \mathrm{cm}^{-1}\right), M_{w}=$ molecular weight of the complex, $g=$ weight of the complex $(\mathrm{g}), \Omega=$ resistance $(\Omega) .{ }^{1} \mathrm{H}-\mathrm{NMR}$ spectra of the ligand, and its $\mathrm{Zn}(\mathrm{II}), \mathrm{Cd}(\mathrm{II})$, and $\mathrm{Hg}$ (II) complexes were obtained on Perkin-Elmer R32-90-MHz spectrophotometer. Chemical shifts ( $\mathrm{ppm}$ ) were reported relative to TMS. ESR measurements of solid complexes at room temperature were made using a Varian E-109 spectrophotometer, using DPPH as a standard material. Mass spectra were recorded using JEULJMS-AX-500 mass spectrometer.

\subsection{Preparation of the Ligand and Its Metal Complexes}

2.2.1. Preparation of the Ligand $\left[\mathrm{H}_{2} \mathrm{~L}\right]$ (1). The ligand $\left(\mathrm{H}_{2} \mathrm{~L}\right)$ was prepared by dropwise addition of equimolar amounts of salicylic hydrazide (2-hydroxy-benzohydrazide) (1.52 g, $0.01 \mathrm{~mol}$ ) dissolved in $20 \mathrm{~mL}$ of absolute ethanol to an ethanolic solution of diacetyl monoxime $(1.29 \mathrm{~g}, 0.01 \mathrm{~mol})$ (Figure 1). The mixture was refluxed with stirring for $4 \mathrm{hrs}$. A dark green precipitate was obtained, filtered off, washed with ethanol, and dried under vacuum over $\mathrm{P}_{2} \mathrm{O}_{5}$. Analytical data of the ligand are given in (Table 1).

2.2.2. Preparation of Metal Complexes, (2)-(17). Complexes (2)-(17) were synthesized by refluxing $25 \mathrm{~mL}$ ethanoic solution of the ligand with $25 \mathrm{~mL}$ ethanolic solution of $3.79 \mathrm{~g}$, 


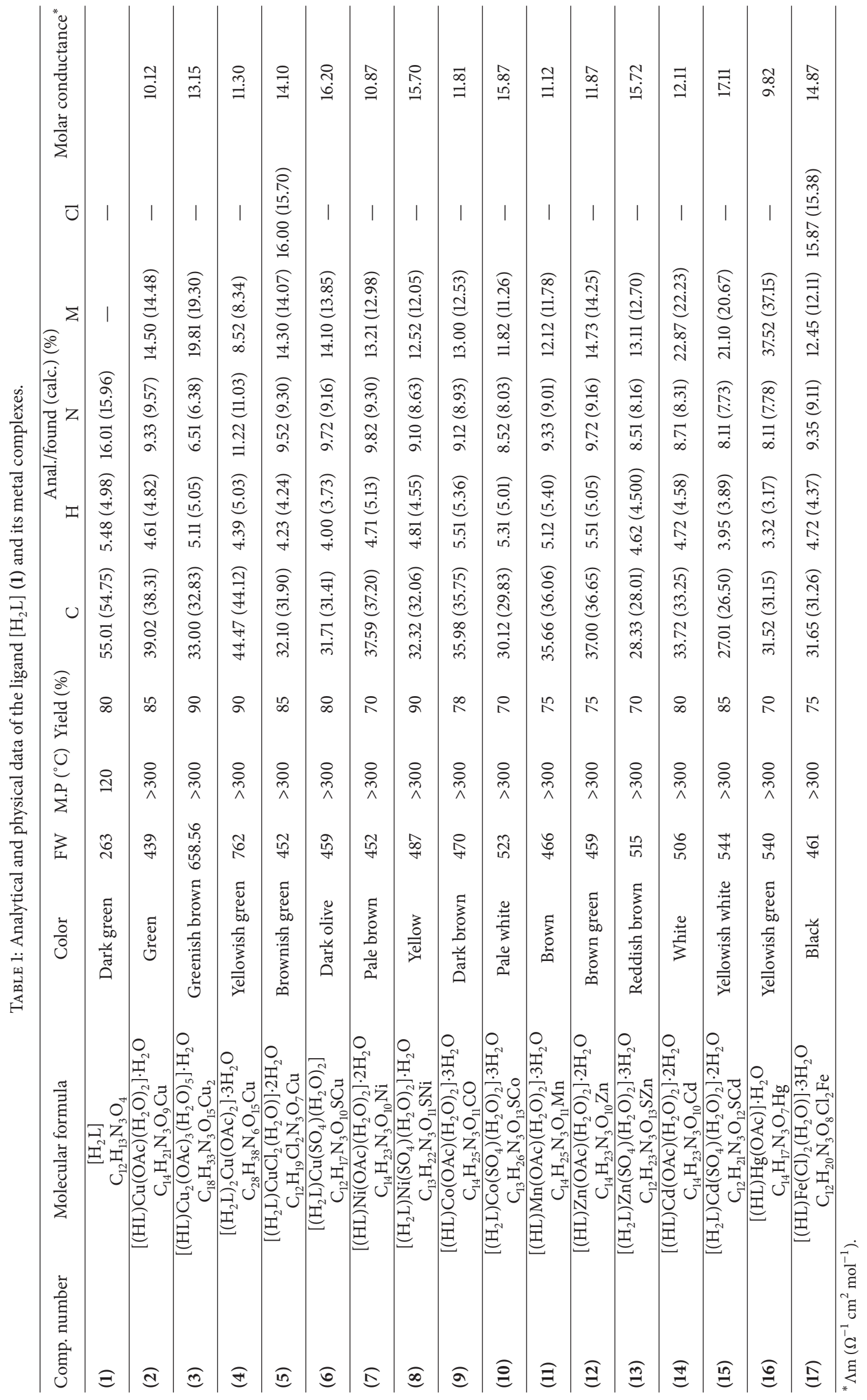


$0.02 \mathrm{~mol}$ of $\mathrm{Cu}(\mathrm{OAc})_{2} \cdot \mathrm{H}_{2} \mathrm{O}(1 \mathrm{~L}: 1 \mathrm{M})$, complex (2); $7.58 \mathrm{~g}$, $0.04 \mathrm{~mol}$ of $\mathrm{Cu}(\mathrm{OAc})_{2} \cdot \mathrm{H}_{2} \mathrm{O}(1 \mathrm{~L}: 2 \mathrm{M})$, complex (3); $1.89 \mathrm{~g}$, $0.01 \mathrm{~mol}$ of $\mathrm{Cu}(\mathrm{OAc})_{2} \cdot \mathrm{H}_{2} \mathrm{O}(2 \mathrm{~L}: 1 \mathrm{M})$, complex (4); $1.88 \mathrm{~g}$, $0.02 \mathrm{~mol}$ of $\mathrm{CuCl}_{2} \cdot 2 \mathrm{H}_{2} \mathrm{O}(1 \mathrm{~L}: 1 \mathrm{M})$, complex (5); $3.03 \mathrm{~g}$, $0.02 \mathrm{~mol}$ of $\mathrm{CuSO}_{4} \cdot 5 \mathrm{H}_{2} \mathrm{O}(1 \mathrm{~L}: 1 \mathrm{M})$, complex (6); $4.73 \mathrm{~g}$, $0.02 \mathrm{~mol}$ of $\mathrm{Ni}(\mathrm{OAc})_{2} \cdot 4 \mathrm{H}_{2} \mathrm{O}(1 \mathrm{~L}: 1 \mathrm{M})$, complex (7); $4.99 \mathrm{~g}$, $0.02 \mathrm{~mol}$ of $\mathrm{NiSO}_{4} \cdot 6 \mathrm{H}_{2} \mathrm{O}(1 \mathrm{~L}: 1 \mathrm{M})$, complex (8); $4.73 \mathrm{~g}$, $0.02 \mathrm{~mol}$ of $\mathrm{Co}(\mathrm{OAc})_{2} \cdot 4 \mathrm{H}_{2} \mathrm{O}(1 \mathrm{~L}: 1 \mathrm{M})$, complex (9); $2.94 \mathrm{~g}$, $0.02 \mathrm{~mol}$ of $\mathrm{CoSO}_{4} \cdot 4 \mathrm{H}_{2} \mathrm{O}(1 \mathrm{~L}: 1 \mathrm{M})$, complex (10); $5.86 \mathrm{~g}$, $0.02 \mathrm{~mol}$ of $4.65 \mathrm{~g}, 0.02 \mathrm{~mol}$ of $\mathrm{Mn}(\mathrm{OAc})_{2} \cdot 4 \mathrm{H}_{2} \mathrm{O}(1 \mathrm{~L}: 1 \mathrm{M})$, complex (11); $4.17 \mathrm{~g}, 0.02 \mathrm{~mol}$ of $\mathrm{Zn}(\mathrm{OAc})_{2} \cdot 2 \mathrm{H}_{2} \mathrm{O}(1 \mathrm{~L}: 1 \mathrm{M})$, complex (12); $3.41 \mathrm{~g}, 0.02 \mathrm{~mol}$ of $\mathrm{ZnSO}_{4} \cdot 4 \mathrm{H}_{2} \mathrm{O}(1 \mathrm{~L}: 1 \mathrm{M})$, complex (13); $5.06 \mathrm{~g}, 0.02 \mathrm{~mol}$ of $\mathrm{Cd}(\mathrm{OAc})_{2} \cdot 2 \mathrm{H}_{2} \mathrm{O}(1 \mathrm{~L}: 1 \mathrm{M})$, complex (14); $4.87 \mathrm{~g}, 0.02 \mathrm{~mol}$ of $\mathrm{CdSO}_{4} \cdot 8 \mathrm{H}_{2} \mathrm{O}(1 \mathrm{~L}: 1 \mathrm{M})$, complex (15); $6.05 \mathrm{~g}, 0.02 \mathrm{~mol}$ of $\mathrm{Hg}(\mathrm{OAc})_{2} \cdot 4 \mathrm{H}_{2} \mathrm{O}(1 \mathrm{~L}: 1 \mathrm{M})$, complex (16); $5.13 \mathrm{~g}, 0.02 \mathrm{~mol}$ of $\mathrm{FeCl}_{3} \cdot 6 \mathrm{H}_{2} \mathrm{O}$ (1L:1M), complex (17). The reaction mixtures were refluxed with stirring for 2-4hrs range, depending on the nature of the metal ion and the anion. The precipitates so formed were filtrated off, washed with ethanol, and dried in vacuum over $\mathrm{P}_{2} \mathrm{O}_{5}$. Analytical data of the metal complexes are given in (Table 1).

2.3. Biological Activity. Evaluation of the cytotoxic activity of the ligand and its metal complexes was carried out in the Pathology Department, Faculty of Medicine, El-Menoufia University, Egypt. The evaluation process was carried out in vitro using the Sulfo-Rhodamine-B-stain (SRB) [25]. Cells were plated in 96-multiwell plate $\left(10^{4}\right.$ cells/well) for $24 \mathrm{hrs}$ before treatment with the complexes to allow attachment of cell to the wall of the plate. Different concentrations of the compounds under test in DMSO $(0,5,12.5,25$, and $50 \mu \mathrm{g} / \mathrm{mL}$ ) were added to the cell monolayer, triplicate wells being prepared for each individual dose. Monolayer cells were incubated with the complexes for $48 \mathrm{hrs}$ at $37^{\circ} \mathrm{C}$ and in atmosphere of $5 \% \mathrm{CO}_{2}$. After 48 hrs, cells were fixed, washed, and stained with Sulfo-Rhodamine-B-stain. Excess stain was wash with acetic acid and attached stain was recovered with Tris EDTA buffer. Color intensity was measured in an ELISA reader. The relation between surviving fraction and drug concentration is plotted to get the survival curve for each tumor cell line after addition the specified compound.

\section{Results and Discussion}

All complexes are colored, stable at room temperature, nonhygroscopic, partially soluble in common organic solvents such as $\mathrm{CHCl}_{3}$, and appreciably soluble in DMF and DMSO. The analytical and physical data (Table 1) and spectral data (Tables 2-4) are compatible with the proposed structures (Figure 2). Many attempts have been made to grow up single crystal but no diffractable crystals have been grown till now. The molar conductances of the complexes in $10^{-3} \mathrm{M} \mathrm{DMF}$ at $25^{\circ} \mathrm{C}$ are in the $13.0-33.4 \mathrm{ohm}^{-1} \mathrm{~cm}^{2} \mathrm{~mol}^{-1}$ range, indicating a nonelectrolytic nature $[26,27]$. The relative high values for some complexes suggest partial dissociation in DMF. The elemental analyses indicated that, all complexes were formed in $1 \mathrm{~L}: 1 \mathrm{M}$ molar ratio, except complex (3) which is found to be formed in $1 \mathrm{~L}: 2 \mathrm{M}$ molar ratio.
3.1. Mass Spectra of the Ligand. The mass spectrum of the $\left[\mathrm{H}_{2} \mathrm{~L}\right]$, ligand showed the molecular ion peak at $\mathrm{m} / \mathrm{e} 263 \mathrm{amu}$, confirming its formula weight (F.W. 363). The mass fragmentation patterns observed at $m / z=76,93,109,121,123,137,180$, 215 , and $263 \mathrm{amu}$ correspond to $\mathrm{C}_{6} \mathrm{H}_{4}, \mathrm{C}_{6} \mathrm{H}_{4} \mathrm{OH}, \mathrm{C}_{6} \mathrm{H}_{5} \mathrm{O}_{2}$, $\mathrm{C}_{7} \mathrm{H}_{5} \mathrm{O}_{2}, \mathrm{C}_{7} \mathrm{H}_{7} \mathrm{O}_{2}, \mathrm{C}_{7} \mathrm{H}_{7} \mathrm{NO}_{2}, \mathrm{C}_{8} \mathrm{H}_{8} \mathrm{~N}_{2} \mathrm{O}_{3}, \mathrm{C}_{8} \mathrm{H}_{13} \mathrm{~N}_{3} \mathrm{O}_{4}$, and $\mathrm{C}_{12} \mathrm{H}_{13} \mathrm{~N}_{3} \mathrm{O}_{4}$ moieties, respectively, supported the suggested structure of the ligand.

3.2. ${ }^{1} H-N M R$ Spectra. The ${ }^{1} \mathrm{H}-\mathrm{NMR}$ spectrum of the ligand indicated the presence of two peaks at $\delta=11.83$ and $12.07 \mathrm{ppm}$ assigned to proton of anti- and syn-oxime $\mathrm{NOH}$ protons, respectively; these two bands disappeared in the presence of $\mathrm{D}_{2} \mathrm{O}$, indicating that these protons are acidic and the hydroxyl group can participate in the coordination with the metal ions. The syn: anti ratio was found to be $1: 1$, indicating that the percentages of free and hydrogen bonded $\mathrm{OHs}$ are identical $[28,29]$. Signals at $\delta=9.73$ and $\delta=10.90 \mathrm{ppm}$ were assigned to the NH protons $[28,30]$. The spectrum showed a set of peaks as multiples in the (7.94-6.81 ppm) range, which were assigned to aromatic protons ring [31]. Peaks which appeared at 2.50 and $2.21 \mathrm{ppm}$ were assigned to acetyl and methyl groups respectively $[17,32]$. These signals disappeared upon adding $\mathrm{D}_{2} \mathrm{O}$.

$\mathrm{Zn}(\mathrm{II}), \mathrm{Cd}(\mathrm{II})$, and $\mathrm{Hg}(\mathrm{II})$ complexes (12), (14), and (16) showed similar spectra. The peaks assigned to the oxime protons disappeared, indicating its participation in the metal coordination. A set of multiple peaks corresponding to the aromatic protons were observed in the $6.88-7.50 \mathrm{ppm}$ range. Signals corresponding to acetyl and methyl prortons appeared at 2.50 and $1.91 \mathrm{ppm}$, respectively [17, 32]; these signals were disappeared upon adding $\mathrm{D}_{2} \mathrm{O}$. A new signal was observed around $1.87 \mathrm{ppm}$, which may be assigned to protons of the coordinated acetate group [33].

3.3. IR Spectra. The characteristic infrared spectral data of ligand $\mathrm{H}_{2} \mathrm{~L}(\mathbf{1})$ and its metal complexes are listed in Table 2. The spectrum of the ligand showed characteristics absorption broad bands in $3360-3315 \mathrm{~cm}^{-1}$ range, which are due to intra- and intermolecular hydrogen bonding of $\mathrm{OH}$ of the oxime groups with the imino nitrogen and carbonyl oxygen atoms [22, 30]. The medium band at $3215 \mathrm{~cm}^{-1}$ was assigned to $(\mathrm{NH})$ group [29]. The band appearing at $1700 \mathrm{~cm}^{-1}$ was assigned to $v(\mathrm{C}=\mathrm{O})$ band, which is less than the expected value. It is deduced, therefore, that the carbonyl group is involved in hydrogen bondings in the ligand. On the other hand, the $v(\mathrm{C}=\mathrm{O})$ band of the amide group appeared at $1664 \mathrm{~cm}^{-1}$ [29]. The $v(\mathrm{C}=\mathrm{N})$ vibrations (imine and oxime groups) appeared at 1613 and $1587 \mathrm{~cm}^{-1}$, respectively [29, 32]. Two strong bands observed at 1147 and $1000 \mathrm{~cm}^{-1}$ which were assigned to $v(\mathrm{~N}-\mathrm{O})[22,34]$. The splitting of the $v\left(\mathrm{~N}_{-}\right.$ $\mathrm{O})$ vibration into two bands confirmed the presence of two nonequivalent hydrogen bonding formations whereby the intramolecular type is stronger than the intermolecular type. The bonding mode of the ligand in the metal complexes has been deduced by comparing the IR spectra of the complexes with that of the free ligand. Ir spectra showed that the ligand coordinated through the nitrogen atoms of the imine and 
<smiles>CC(=O)C(=NO)C(C)=O</smiles>

(E)-2-Hydroxy- $\mathrm{N}^{\prime}$-((Z)-3-(hydroxyimino)-4-oxopentan-2-ylidene)benzohydrazide Ligand $\mathrm{H}_{2} \mathrm{~L}$

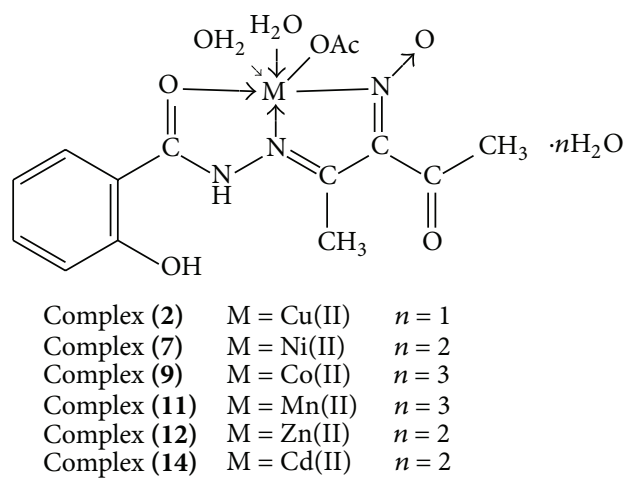

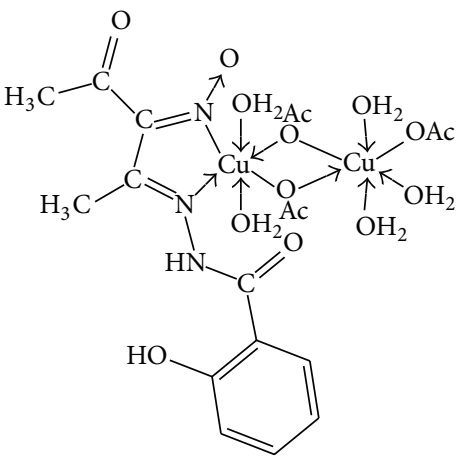<smiles></smiles>

Complex (3)

Complex (4)<smiles>CC(=O)C1=C(C)N(NC(=O)c2ccccc2O)N(O)C(Cl)=C1Cl</smiles><smiles></smiles>

$$
\begin{array}{lll}
\text { Complex (6) } & \mathrm{M}=\mathrm{Cu}(\mathrm{II}) & n=0 \\
\text { Complex (8) } & \mathrm{M}=\mathrm{Ni}(\mathrm{II}) & n=1 \\
\text { Complex (10) } & \mathrm{M}=\mathrm{Co}(\mathrm{II}) & n=3 \\
\text { Complex (13) } & \mathrm{M}=\mathrm{Zn}(\mathrm{II}) & n=3 \\
\text { Complex (15) } & \mathrm{M}=\mathrm{Cd}(\mathrm{II}) & n=2
\end{array}
$$<smiles>CC(=O)C1=C(C)N(NC(=O)c2ccccc2O)N(OC(C)(C)C)N1[O-]</smiles>

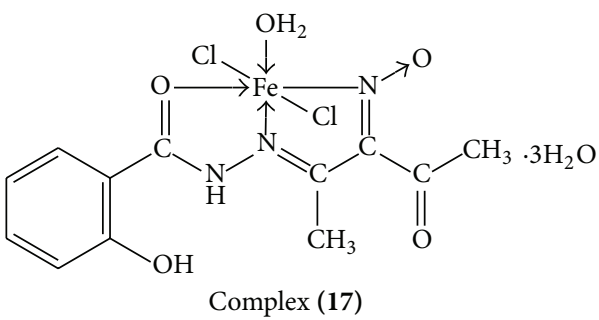

Figure 2: Proposed structures of the ligand $\left[\mathrm{H}_{2} \mathrm{~L}\right]$ and its metal complexes. 


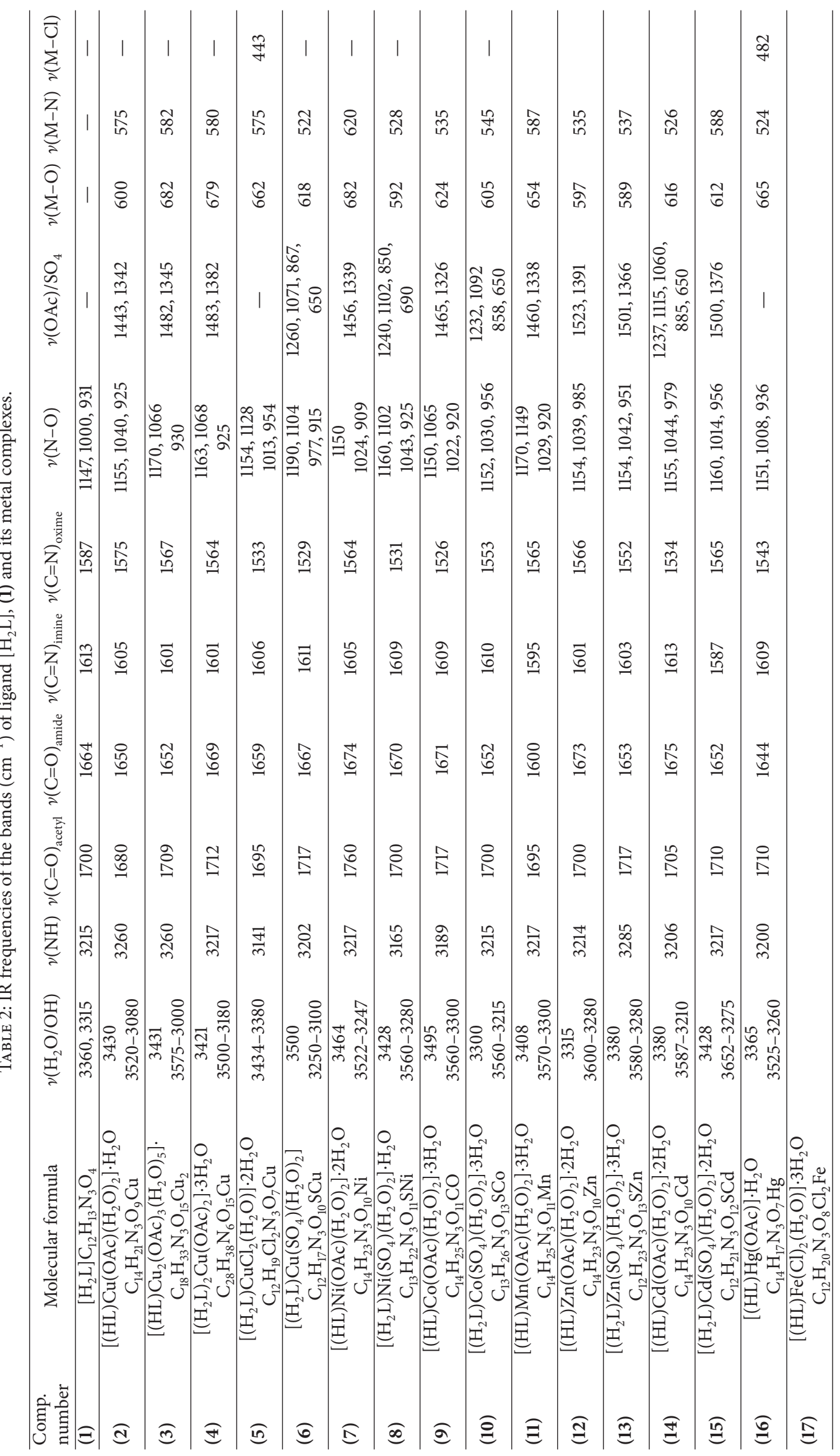


TABLE 3: Electronic spectra (nm) and magnetic moments (BM) for the ligand (1) and metal complexes.

\begin{tabular}{|c|c|c|c|c|}
\hline Comp. number & Molecular formula & $\lambda_{\max }(\mathrm{nm})$ & $\mu_{\mathrm{eff}}(\mathrm{BM})$ & $v_{2} / v_{1}$ \\
\hline (1) & {$\left[\mathrm{H}_{2} \mathrm{~L}\right] \mathrm{C}_{12} \mathrm{H}_{13} \mathrm{~N}_{3} \mathrm{O}_{4}$} & $\begin{array}{l}275 \mathrm{~nm}\left(\varepsilon=5.86 \times 10^{-4} \mathrm{~L} \mathrm{~mol}^{-1} \mathrm{~cm}^{-1}\right) \\
315 \mathrm{~nm}\left(\varepsilon=8.45 \times 10^{-4} \mathrm{~L} \mathrm{~mol}^{-1} \mathrm{~cm}^{-1}\right) \\
350 \mathrm{~nm}\left(\varepsilon=9.20 \times 10^{-4} \mathrm{~L} \mathrm{~mol}^{-1} \mathrm{~cm}^{-1}\right)\end{array}$ & - & - \\
\hline (2) & $\begin{array}{c}{\left[(\mathrm{HL}) \mathrm{Cu}(\mathrm{OAc})\left(\mathrm{H}_{2} \mathrm{O}\right)_{2}\right] \cdot \mathrm{H}_{2} \mathrm{O}} \\
\mathrm{C}_{14} \mathrm{H}_{21} \mathrm{~N}_{3} \mathrm{O}_{9} \mathrm{Cu}\end{array}$ & $265,302,380,495,550,625$ & 1.79 & - \\
\hline (3) & $\begin{array}{c}{\left[(\mathrm{HL}) \mathrm{Cu}_{2}(\mathrm{OAc})_{3}\left(\mathrm{H}_{2} \mathrm{O}\right)_{5}\right] \cdot} \\
\mathrm{C}_{18} \mathrm{H}_{33} \mathrm{~N}_{3} \mathrm{O}_{15} \mathrm{Cu}_{2}\end{array}$ & $268,308,380,425,550,626$ & 1.68 & - \\
\hline (4) & $\begin{array}{c}{\left[\left(\mathrm{H}_{2} \mathrm{~L}\right)_{2} \mathrm{Cu}(\mathrm{OAc})_{2}\right] \cdot 3 \mathrm{H}_{2} \mathrm{O}} \\
\mathrm{C}_{28} \mathrm{H}_{38} \mathrm{~N}_{6} \mathrm{O}_{15} \mathrm{Cu}\end{array}$ & $270,370,390,450,570,610$ & 1.81 & - \\
\hline (5) & $\begin{array}{c}{\left[\left(\mathrm{H}_{2} \mathrm{~L}\right) \mathrm{CuCl}_{2}\left(\mathrm{H}_{2} \mathrm{O}\right)\right] \cdot 2 \mathrm{H}_{2} \mathrm{O}} \\
\mathrm{C}_{12} \mathrm{H}_{19} \mathrm{Cl}_{2} \mathrm{~N}_{3} \mathrm{O}_{7} \mathrm{Cu}\end{array}$ & $260,300,370,460,565,605$ & 1.77 & - \\
\hline (6) & $\begin{array}{c}{\left[\left(\mathrm{H}_{2} \mathrm{~L}\right) \mathrm{Cu}\left(\mathrm{SO}_{4}\right)\left(\mathrm{H}_{2} \mathrm{O}\right)_{2}\right]} \\
\mathrm{C}_{12} \mathrm{H}_{17} \mathrm{~N}_{3} \mathrm{O}_{10} \mathrm{SCu}\end{array}$ & $265,300,400,505,595,605$ & 1.78 & - \\
\hline (7) & $\begin{array}{c}{\left[(\mathrm{HL}) \mathrm{Ni}(\mathrm{OAc})\left(\mathrm{H}_{2} \mathrm{O}\right)_{2}\right] \cdot 2 \mathrm{H}_{2} \mathrm{O}} \\
\mathrm{C}_{14} \mathrm{H}_{23} \mathrm{~N}_{3} \mathrm{O}_{10} \mathrm{Ni}\end{array}$ & $272,303,420,525,617,687,749$ & 2.85 & 1.06 \\
\hline (8) & $\begin{array}{c}{\left[\left(\mathrm{H}_{2} \mathrm{~L}\right) \mathrm{Ni}\left(\mathrm{SO}_{4}\right)\left(\mathrm{H}_{2} \mathrm{O}\right)_{2}\right] \cdot \mathrm{H}_{2} \mathrm{O}} \\
\mathrm{C}_{13} \mathrm{H}_{22} \mathrm{~N}_{3} \mathrm{O}_{11} \mathrm{SNi}\end{array}$ & $265,300,415,510,620,690,720$ & 2.95 & 1.04 \\
\hline (9) & $\begin{array}{c}{\left[(\mathrm{HL}) \mathrm{Co}(\mathrm{OAc})\left(\mathrm{H}_{2} \mathrm{O}\right)_{2}\right] \cdot 3 \mathrm{H}_{2} \mathrm{O}} \\
\mathrm{C}_{14} \mathrm{H}_{25} \mathrm{~N}_{3} \mathrm{O}_{11} \mathrm{CO}\end{array}$ & $275,301,420,598,620$ & 5.11 & 1.03 \\
\hline (10) & $\begin{array}{c}{\left[\left(\mathrm{H}_{2} \mathrm{~L}\right) \mathrm{Co}\left(\mathrm{SO}_{4}\right)\left(\mathrm{H}_{2} \mathrm{O}\right)_{2}\right] \cdot 3 \mathrm{H}_{2} \mathrm{O}} \\
\mathrm{C}_{13} \mathrm{H}_{26} \mathrm{~N}_{3} \mathrm{O}_{13} \mathrm{SCo}\end{array}$ & $302,397,430,556,621,265$ & 5.52 & 1.11 \\
\hline (11) & $\begin{array}{c}{\left[(\mathrm{HL}) \mathrm{Mn}(\mathrm{OAc})\left(\mathrm{H}_{2} \mathrm{O}\right)_{2}\right] \cdot 3 \mathrm{H}_{2} \mathrm{O}} \\
\mathrm{C}_{14} \mathrm{H}_{25} \mathrm{~N}_{3} \mathrm{O}_{11} \mathrm{Mn}\end{array}$ & $265,298,390,425,585,611$ & 6.10 & - \\
\hline (12) & $\begin{array}{c}{\left[(\mathrm{HL}) \mathrm{Zn}(\mathrm{OAc})\left(\mathrm{H}_{2} \mathrm{O}\right)_{2}\right] \cdot 2 \mathrm{H}_{2} \mathrm{O}} \\
\mathrm{C}_{14} \mathrm{H}_{23} \mathrm{~N}_{3} \mathrm{O}_{10} \mathrm{Zn}\end{array}$ & $270,305,365$ & Diamagnetic & - \\
\hline (13) & $\begin{array}{c}{\left[\left(\mathrm{H}_{2} \mathrm{~L}\right) \mathrm{Zn}\left(\mathrm{SO}_{4}\right)\left(\mathrm{H}_{2} \mathrm{O}\right)_{2}\right] \cdot 3 \mathrm{H}_{2} \mathrm{O}} \\
\mathrm{C}_{12} \mathrm{H}_{23} \mathrm{~N}_{3} \mathrm{O}_{13} \mathrm{SZn}\end{array}$ & $265,300,378$ & Diamagnetic & - \\
\hline (14) & $\begin{array}{c}{\left[(\mathrm{HL}) \mathrm{Cd}(\mathrm{OAc})\left(\mathrm{H}_{2} \mathrm{O}\right)_{2}\right] \cdot 2 \mathrm{H}_{2} \mathrm{O}} \\
\mathrm{C}_{14} \mathrm{H}_{23} \mathrm{~N}_{3} \mathrm{O}_{10} \mathrm{Cd}\end{array}$ & $268,305,360$ & Diamagnetic & - \\
\hline (15) & $\begin{array}{c}{\left[\left(\mathrm{H}_{2} \mathrm{~L}\right) \mathrm{Cd}\left(\mathrm{SO}_{4}\right)\left(\mathrm{H}_{2} \mathrm{O}\right)_{2}\right] \cdot 2 \mathrm{H}_{2} \mathrm{O}} \\
\mathrm{C}_{12} \mathrm{H}_{21} \mathrm{~N}_{3} \mathrm{O}_{12} \mathrm{SCd}\end{array}$ & $265,302,370$ & Diamagnetic & - \\
\hline (16) & $\begin{array}{c}{[(\mathrm{HL}) \mathrm{Hg}(\mathrm{OAc})] \cdot \mathrm{H}_{2} \mathrm{O}} \\
\mathrm{C}_{14} \mathrm{H}_{17} \mathrm{~N}_{3} \mathrm{O}_{7} \mathrm{Hg} \\
\end{array}$ & $260,305,370$ & Diamagnetic & - \\
\hline (17) & $\begin{array}{c}{\left[(\mathrm{HL}) \mathrm{Fe}(\mathrm{Cl})_{2}\left(\mathrm{H}_{2} \mathrm{O}\right)\right] \cdot 3 \mathrm{H}_{2} \mathrm{O}} \\
\mathrm{C}_{12} \mathrm{H}_{20} \mathrm{~N}_{3} \mathrm{O}_{8} \mathrm{Cl}_{2} \mathrm{Fe}\end{array}$ & $265,302,330,475,541,615$ & 6.11 & - \\
\hline
\end{tabular}

the oximato $(\mathrm{C}=\mathrm{N} \rightarrow \mathrm{O})$ groups. This mode of bonding is supported by negative shifts in bands of these groups and simultaneous increasing in $(\mathrm{N} \rightarrow \mathrm{O})$ band, appearing in the $1150-1170 \mathrm{~cm}^{-1}$ range $[35,36]$. In all complexes except complexes (3) and (4), the strong band assigned to $v(\mathrm{C}=\mathrm{O})$ amid stretching band was shifted to lower frequency, indicating involvement of amide keto oxygen in the metal coordinating. The appearance of two characteristic bands at 1482, 1483, 1500 , and $1345,1382,1376 \mathrm{~cm}^{-1}$ in spectra of complexes (3), $(4)$, and (16), respectively, were attributed to $v_{\text {asym. }}\left(\mathrm{COO}^{-}\right)$ and $v_{\text {sym. }}\left(\mathrm{COO}^{-}\right)$, respectively, indicating the participation of the acetate oxygen in the complex formation [37]. The mode of coordination of acetate group has often been deduced from the magnitude of the observed separation between the $v_{\text {asym. }}\left(\mathrm{COO}^{-}\right)$and $v_{\text {sym. }}\left(\mathrm{COO}^{-}\right)$. The separation value $(\Delta)$ between $v_{\text {asym. }}\left(\mathrm{COO}^{-}\right)$and $v_{\text {sym. }}\left(\mathrm{COO}^{-}\right)$for these complexes were 137,101 , and $124 \mathrm{~cm}^{-1}$ suggesting the coordination of acetate group in a monodentate fashion $[38,39]$. In addition, complex (3) showed $v\left(\mathrm{CO}_{2}\right)$ at 1560 and $1425 \mathrm{~cm}^{-1}$ due to a bridging acetate group. The chloro complexes (5) and (17) showed new bands at 443 and $482 \mathrm{~cm}^{-1}$, respectively, this band was assigned to $v(\mathrm{M}-\mathrm{Cl})$, whereas sulphate complexes (6), (8), (10), (13), and (15) exhibited new bands in the (12321260), (1004-1115), (850-885), and (650-690) $\mathrm{cm}^{-1}$ ranges, these values indicated that the sulphate ion is coordinated to the metal ion in a unidentate chelating fashion $[35,40]$. The mode of coordination is supported by presence of additional bands in 620-528 and 682-592 $\mathrm{cm}^{-1}$ regions corresponding to $v(\mathrm{M}-\mathrm{N})$ and $v(\mathrm{M}-\mathrm{O})$ bands, respectively $[22,36,41]$.

3.4. Electronic Spectra and Magnetic Moments. The electronic absorption spectral data of the ligand and its metal complexes in DMF are listed in Table 3. The ligand showed three bands at $275 \mathrm{~nm}\left(5.86 \times 10^{-4} \mathrm{~L} \mathrm{~mol}^{-1} \mathrm{~cm}^{-1}\right)$ and $315 \mathrm{~nm}$ 


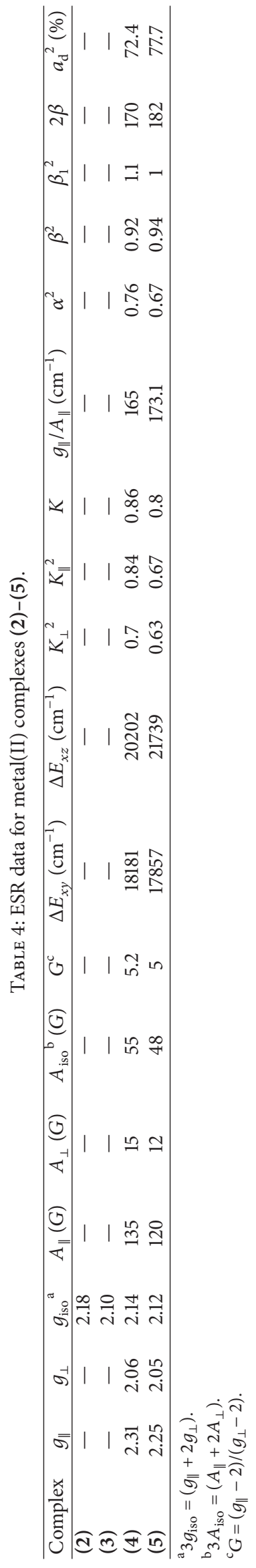


$\left(\varepsilon=8.45 \times 10^{-4} \mathrm{~L} \mathrm{~mol}^{-1} \mathrm{~cm}^{-1}\right)$ and $350 \mathrm{~nm}(\varepsilon=9.2 \times$ $10^{-4} \mathrm{~L} \mathrm{~mol}^{-1} \mathrm{~cm}^{-1}$ ). The first band may be assigned to $\pi \rightarrow$ $\pi^{*}$ transition which is nearly unchanged upon complexation, whereas the second and third bands may be assigned to the $\mathbf{n} \rightarrow \pi^{*}$ and charge transfer transitions of the azomethine and carbonyl groups $[30,42]$. These two bands were shifted to lower energy upon complex formation, indicating participation of these groups in coordination with the metal ions. The electronic spectra of copper(II) complexes (2)-(6) were nearly identical and showing bands centered in the 425$505,550-595$, and 605-626 $\mathrm{nm}$ ranges assigned to ${ }^{2} \mathrm{~B}_{1 \mathrm{~g}} \rightarrow$ ${ }^{2} \mathrm{~A}_{1 \mathrm{~g}} v_{1}\left(\mathrm{~d}_{x^{2}-y^{2}} \rightarrow \mathrm{d}_{z^{2}}\right),{ }^{2} \mathrm{~B}_{1 \mathrm{~g}} \rightarrow{ }^{2} \mathrm{~B}_{2 \mathrm{~g}}, v_{2}\left(\mathrm{~d}_{x^{2}-y^{2}} \rightarrow \mathrm{d}_{x y}\right)$, and ${ }^{2} \mathrm{~B}_{1 \mathrm{~g}} \rightarrow{ }^{2} \mathrm{E}_{\mathrm{g}}, v_{3}\left(\mathrm{~d}_{x^{2}-y^{2}} \rightarrow \mathrm{d}_{x y}, \mathrm{~d}_{y z}\right)$ transitions, respectively. These transitions indicated that the copper(II) ion has a tetragonally distorted octahedral geometry. This could be due to the Jahn-Teller effect that operates on the $\mathrm{d}^{9}$ electronic ground state of six coordinate system, elongating one trans pair of coordinate bonds and shortening the remaining four ones [43]. The magnetic moments for copper(II) complexes at room temperature were in the 1.68-1.81 range BM, supporting that the complexes have octahedral geometry [44]. The low magnetic moments values of complexes (3) and (4) may be due spin-spin interactions between copper(II) [44]. Nickel(II) complexes (7) and (8) displayed three bands at 420 , 617,749 and $415,620,720 \mathrm{~nm}$, respectively, these bands were assigned to ${ }^{3} \mathrm{~A}_{2 \mathrm{~g}}(\mathrm{~F}) \rightarrow{ }^{3} \mathrm{~T}_{2 \mathrm{~g}}(\mathrm{~F}) v_{1},{ }^{3} \mathrm{~A}_{2 \mathrm{~g}}(\mathrm{~F}) \rightarrow{ }^{3} \mathrm{~T}_{2 \mathrm{~g}}\left(v_{2}\right)$, and ${ }^{3} \mathrm{~A}_{2 \mathrm{~g}}(\mathrm{~F}) \rightarrow{ }^{3} \mathrm{~T}_{1 \mathrm{~g}}(\mathrm{P}) v_{3}$ transitions, indicating octahedral nickel(II) complexes $[26,45]$. The $v_{2} / v_{1}$ ratios were 1.06 and 1.04 for complexes (7) and (8), respectively, which are less than the usual range of 1.5-1.75, indicating distorted octahedral nickel(II) complex [26, 45]. The values of magnetic moments for nickel(II) complex (7) and (8) were 2.82 and $2.85 \mathrm{BM}$, respectively, which are consistent with two unpaired electrons state, confirming octahedral geometry for nickel(II) [45]. The cobalt(II) complexes (9) and (10) exhibited only two bands at $(598,620)$ and $(556,621) \mathrm{nm}$ ranges, respectively. These bands were assigned to ${ }^{4} \mathrm{~T}_{1 \mathrm{~g}}(\mathrm{~F}) \rightarrow{ }^{4} \mathrm{~T}_{2 \mathrm{~g}}(\mathrm{~F}) v_{1}$ and ${ }^{4} \mathrm{~T}_{1 \mathrm{~g}}(\mathrm{~F}) \rightarrow{ }^{4} \mathrm{~A}_{2 \mathrm{~g}}(\mathrm{~F}) v_{2}$ transitions, respectively. The third transition band has not been observed possibly because it is out the range of spectrophotometer $(>900 \mathrm{~nm})$. The lower value of $v_{2} / v_{1}$ complex (9) and complex (10) may be due to distortion of the octahedral structures [26]. The magnetic moments for cobalt(II) complexes (9) and (10) at room temperature recorded 5.11 and $5.52 \mathrm{BM}$, respectively. These values are consistent with high spin cobalt(II) ion $\left(d^{7}\right)$. Manganese(II) complex (11) displayed weak bands at 425, 585 , and $611 \mathrm{~nm}$. These bands were assigned to ${ }^{6} \mathrm{~A}_{1 \mathrm{~g}} \rightarrow$ ${ }^{4} \mathrm{E}_{\mathrm{g}},{ }^{6} \mathrm{~A}_{1 \mathrm{~g}} \rightarrow{ }^{4} \mathrm{~T}_{2 \mathrm{~g}}$, and ${ }^{6} \mathrm{~A}_{1 \mathrm{~g}} \rightarrow{ }^{4} \mathrm{~T}_{1 \mathrm{~g}}$ transitions, respectively, corresponding to an octahedral structure for manganese(II) complex $[43,46]$. Since all the excited states of $\mathrm{Mn}$ (II) ion either quartets or doublets, the absorption spectra of $\mathrm{Mn}$ (II) ions have only spin forbidden transitions. Therefore, the intensity of transitions was weak. The value of magnetic moment for manganese(II) complex (11) is 6.10 BM which is consistent with high spin octahedral geometry for manganese(II) [41, 47]. Iron(III) complex (17) showed bands at 475,541 , and $615 \mathrm{~nm}$. The first transition is related to charge transfer from the ligand to iron(III) ion, whereas the other two bands were assigned to ${ }^{6} \mathrm{~A}_{1 \mathrm{~g}} \rightarrow{ }^{4} \mathrm{~T}_{1 \mathrm{~g}}$ and ${ }^{6} \mathrm{~A}_{1 \mathrm{~g}} \rightarrow{ }^{4} \mathrm{~T}_{2 \mathrm{~g}}$ transitions, suggesting a distorted octahedral structure around the iron atom $[46,48]$. The recorded magnetic moment (6.11 BM) is consistent with the proposed high spin octahedral geometry for iron(III) complex [41, 47]. The observed bands in zinc(II) (12) and (13), cadmium(II) (14) and (15), and mercury(II) (16) complexes (Table 3) are due to interligand transitions within the ligand.

3.5. Electron Spin Resonance (ESR). The ESR spectra of solid copper(II) complexes (2)-(5) at room temperature are characteristic of a species with a $\mathrm{d}^{9}$ configuration and having an axial symmetry type of a $\mathrm{d}_{\left(x^{2}-y^{2}\right)}$ ground state, which is the most common for copper(II) complexes [22]. Complexes (2) and (3) showed isotropic type with $g_{\text {iso }}=2.18$ and 2.10, whereas complexes (4) and (5) showed axial type with $g_{\|}>$ $g_{\perp}>2.04$, indicating a tetragonal distortion $[26,33]$, corresponding to elongation along the fold symmetry axis $Z$. The $g$-values are related by the expression $G=\left(g_{\|}-2\right) /\left(g_{\perp}-2\right)$. If $G>4.0$, then, the local tetragonal axes are aligned parallel or only slightly misaligned; if $G<4.0$, the significant exchange coupling is present. Complexes (4) and (5) showed $G$ value $\geq 4.0$, indicating that tetragonal axes are present. Also, these complexes showed $\mathrm{g}_{\|} \leq 2.3$, suggesting considerable covalent bond character around the copper(II) ion $[49,50]$. Also, the in-plane $\sigma$-covalence parameter, $\alpha^{2}(\mathrm{Cu})$, was calculated by

$$
\begin{aligned}
\alpha^{2}(\mathrm{Cu})= & \left(\frac{A_{\|}}{0.036}\right)+\left(g_{\|}-2.002\right)+\frac{3}{7}\left(g_{\perp}-2.002\right) \\
& +0.04
\end{aligned}
$$

The calculated values for (4) and (5) are 0.76 and 0.67 (Table 4), suggesting covalent bond character [26, 51]. The $g_{\|} / A_{\|}$is taken as an indication for the stereochemistry of the copper(II) complexes. Karlin has suggested that this ratio may be an empirical indication of the stereochemistry of copper(II) complex [52]. The value $g_{\|} / A_{\|}$quotient in the (165-173.1) $\mathrm{cm}^{-1}$ range is expected for copper(II) complexes within perfectly square based geometry and those higher than $150 \mathrm{~cm}^{-1}$ for tetragonally distorted complexes. The values for copper(II) complexes (4) and (5) are associated with a tetragonally distorted field around copper(II) centers. For copper(II) complexes with ${ }^{2} \mathrm{~B}_{1}$ ground state, the $g$-values can be related to the parallel $\left(K_{\|}\right)$and perpendicular $\left(K_{\perp}\right)$ components of the orbital reduction factor $\left(K_{\perp}\right)$ as follows [51]:

$$
\begin{aligned}
K_{\|}^{2} & =\frac{\left(g_{\|}-2.0023\right) \Delta E_{x y}}{8 \lambda_{o}}, \\
K_{\perp}{ }^{2} & =\frac{\left(g_{\perp}-2.0023\right) \Delta E_{x z}}{2 \lambda_{o}}, \\
K^{2} & =\frac{\left(K_{\|}^{2}+2 K_{\perp}^{2}\right)}{3},
\end{aligned}
$$

where $\lambda_{o}$ is the spine orbit coupling of free copper ion $\left(-828 \mathrm{~cm}^{-1}\right)$ and $\Delta E_{x y}$ and $\Delta E_{x z}$ are the electronic transition energies of ${ }^{2} \mathrm{~B}_{1} \rightarrow{ }^{2} \mathrm{~B}_{2}$ and ${ }^{2} \mathrm{~B}_{1} \rightarrow{ }^{2} \mathrm{E}$, respectively. For the 
purpose of calculation, it was assumed that the maximum in the band corresponds to $\Delta E_{x y}$ and $\Delta E_{x z}$ can be taken from the wavelength of these bands. From the above relations, the orbital reduction factors $\left(K_{\|}, K_{\perp}\right.$, and $\left.K\right)$ which are a measure of covalence can be calculated. For an ionic environment, $K=1$, and for a covalent environment, $K<1$, the lower the value of $K$, the greater the covalent character. The values of $K$ for (4) and (5) (Table 4) showed considerable covalent bond character. The in-plane and out-of-plane $\pi$-bonding coefficients $\left(\beta_{1}^{2}\right.$ and $\left.\beta^{2}\right)$, respectively, are dependent upon to values of $\Delta E_{x y}$ and $\Delta E_{x z}$ in the following equations [53]:

$$
\begin{aligned}
\alpha^{2} \beta^{2} & =\frac{\left(g_{\perp}-2.002\right) \Delta E}{2 \lambda^{\circ}}, \\
\alpha^{2} \beta_{1}^{2} & =\frac{\left(g_{\|}-2.002\right) \Delta E}{8 \lambda^{o}} .
\end{aligned}
$$

Complexes (4) and (5) showed $\beta_{1}{ }^{2}$ values 1.1 and 1.0, indicating a moderate degree of ionic character in the inplane $\pi$-bonding, while $\beta^{2}$ are 0.92 and 0.94 , indicating ionic character in the out-of-plane $\pi$-bonding [54]. It is possible to calculate the approximate orbital population for $\mathrm{d}$ orbital using the following equations [22]:

$$
\begin{aligned}
& A_{\|}=A_{\text {iso }}-2 B\left(1 \pm \frac{7}{4}\right) \Delta g_{\|} \\
& a_{\mathrm{d}}^{2}=\frac{2 B}{2 B^{o}}
\end{aligned}
$$

where $2 B^{o}$ is the calculated dipolar coupling for unit occupancy of the d orbital. When the data of complexes (4) and (5) are analyzed, the results suggested an orbital population close to 72.4 and $77.7 \%$ d-orbital spin density clearly, the orbit of the unpaired electron is a $\mathrm{d}_{\left(x^{2}-y^{2}\right)}$ ground state [22]. The ESR spectral data, for copper(II) complexes are shown in Table 4. $\mathrm{Co}(\mathrm{II})$ (9) and $\mathrm{Mn}$ (II) (11) complex showed isotropic spectra with $g_{\text {iso }}=2.1$ and 2.003 , respectively.

3.6. Thermal Analyses (DTA and TGA). IR spectral data (Table 2) indicates the presence of water molecules; thermal analyses were carried out to ascertain their nature, and to give an insight into the thermal stability of the studied compounds. The results showed that there is a good agreement in the weight loss between the calculated and the proposed formulae. The thermal analyses imply that all complexes generally decomposed in several steps (Table 5). The DTA and TGA thermogram of complex (4) showed that the complex decomposed in four steps. The first peak at $120^{\circ} \mathrm{C}$ with a weight loss of $7.0 \%$ (calcd. $7.08 \%$ ) is assigned to elimination of three hydrated water molecules, which is accompanied by an endothermic peak. The second step appeared as an exothermic peak at $160^{\circ} \mathrm{C}$, assigned to loss of two $\mathrm{CH}_{3} \mathrm{COOH}$ molecules with weight loss $7.81 \%$ (calcd. 7.74\%). The third step appeared as an exothermic peak at $298^{\circ} \mathrm{C}$, referring to melting point of the complex. The fourth step at $475^{\circ} \mathrm{C}$ with a weight loss of $73.36 \%$ (calcd. 74.48) implies completing decomposition of this complex that ended with the formation $\mathrm{CuO}$ that is accompanied by an exothermic peak. The TG and
DTA thermogram of complex (8) showed that the complex decomposed in four steps. The first peak at $90^{\circ} \mathrm{C}$ with a weight loss of $3.69 \%$ (calcd. $3.60 \%$ ) assigned to the elimination one hydrated water molecule, which is accompanied by an endothermic peak. The second step at $195^{\circ} \mathrm{C}$ with a weight loss of $7.48 \%$ (calcd. $7.39 \%$ ) is assigned to elimination of two coordinating water molecules that is accompanied by an endothermic peak. The third step appeared as an exothermic peak at $275^{\circ} \mathrm{C}$, assigned to loss of one $\mathrm{H}_{2} \mathrm{SO}_{4}$ molecule with weight loss 20.27 (calcd. 20.13\%). The fourth step appeared as an exothermic peak at $400^{\circ} \mathrm{C}$, referring to melting point of the complex. The fifth step at $460^{\circ} \mathrm{C}$ with a weight loss of $67.51 \%$ (calcd. 68.73) implies the complete decomposition of this complex that ended with the formation $\mathrm{NiO}$ that is accompanied by an exothermic peak. The TG and DTA thermogram of complexes (9) and (11) showed that these complexes decomposed in five steps. The first peak appeared at 79 and $90^{\circ} \mathrm{C}$ with a weight loss of 11.60 and $11.87 \%$ (calcd. 11.49 and $11.74 \%$ ), respectively, is assigned to removal of three hydrated water molecules from each complex; this weight loss is accompanied by an endothermic peak. The second peak at 140 and $170^{\circ} \mathrm{C}$ with a weight loss of 7.24 and $7.90 \%$ (calcd. 7.35 and $7.73 \%$ ) is assigned to elimination of two coordinated water molecules from each complex; this is accompanied by an endothermic peak. The third step at 170 and 258 associated a weight loss of 12.46 and $12.86 \%$ (calcd. 12.25 and $13.04 \%$ ) is assigned to the elimination of one acetate ion from each complex, this step accompanied with endothermic peak. The fourth step appeared as an exothermic peak at 325 and $319^{\circ} \mathrm{C}$, referring to the melting point of the two complexes, respectively. The fifth step at 450 and $445^{\circ} \mathrm{C}$ with a weight loss of 51.79 and $64.13 \%$ (calcd. 52.98 and 65.18) implies to complete decomposition of these complexes, respectively, leaving metal oxide that is accompanied by an exothermic peak:

$$
\begin{aligned}
& {\left[(\mathrm{HL}) \mathrm{Cu}(\mathrm{OAc})\left(\mathrm{H}_{2} \mathrm{O}_{2}\right] \cdot 2 \mathrm{H}_{2} \mathrm{O}\right.} \\
& \quad \stackrel{60^{\circ} \mathrm{C}}{\longrightarrow}\left[(\mathrm{HL}) \mathrm{Cu}(\mathrm{OAc})\left(\mathrm{H}_{2} \mathrm{O}\right)_{2}\right] \cdot 2 \mathrm{H}_{2} \mathrm{O} \\
& {\left[(\mathrm{HL}) \mathrm{Cu}(\mathrm{OAc})\left(\mathrm{H}_{2} \mathrm{O}\right)_{2}\right]} \\
& \quad \stackrel{150^{\circ} \mathrm{C}}{\longrightarrow}[(\mathrm{HL}) \mathrm{Cu}(\mathrm{OAc})]+2 \mathrm{H}_{2} \mathrm{O} \\
& {[(\mathrm{HL}) \mathrm{Cu}(\mathrm{OAc})] \stackrel{265^{\circ} \mathrm{C}}{\longrightarrow}[(\mathrm{L}) \mathrm{Cu}]+\mathrm{CH}_{3} \mathrm{COOH}} \\
& {[(\mathrm{L}) \mathrm{Cu}] \stackrel{570^{\circ} \mathrm{C}}{\longrightarrow} \mathrm{CuO}+\text { organic residues }}
\end{aligned}
$$

3.7. Cytotoxicity Activity. The cytotoxic activity of the oxime hydrazone ligand $\mathrm{H}_{2} \mathrm{~L}$ (1) and its metal complexes (2), (3), (4), and (9) was evaluated against human liver HepG2 cancer cell, (HepG2 cell line) within $0.1-100 \mu \mathrm{g} / \mathrm{L}$ concentration range. The $\mathrm{IC}_{50}$ values were calculated for each compound and results are presented in Figure 3 and Table 6. As shown, most complexes displayed significantly cytotoxic activities compared to Sorafenib (Nexavar) standard drug. It seems that changing the anion, coordination sites, and the nature of the metal ion has effect on the biological behavior. Cytotoxicity 
TABLE 5: Thermal analyses for metal complexes.

\begin{tabular}{|c|c|c|c|c|c|c|c|}
\hline \multirow{2}{*}{\multicolumn{2}{|c|}{ Comp. number Molecular formula }} & \multirow{2}{*}{ Temp. $\left({ }^{\circ} \mathrm{C}\right)$} & \multicolumn{2}{|c|}{ DTA (peak) } & \multicolumn{2}{|c|}{ TGA (Wt. loss \%) } & \multirow{2}{*}{ Assignments } \\
\hline & & & Endo & Exo & Calc. & Found & \\
\hline \multirow{7}{*}{$(4)$} & \multirow{7}{*}{$\begin{array}{l}{\left[\left(\mathrm{H}_{2} \mathrm{~L}\right)_{2} \mathrm{Cu}(\mathrm{OAc})_{2}\right] \cdot 3 \mathrm{H}_{2} \mathrm{O}} \\
\mathrm{C}_{28} \mathrm{H}_{38} \mathrm{~N}_{6} \mathrm{O}_{15} \mathrm{Cu}\end{array}$} & 120 & Endo & - & 7.08 & 7.00 & Loss of hydrated $3 \mathrm{H}_{2} \mathrm{O}$ \\
\hline & & 160 & Endo & - & 8.33 & 8.27 & Loss of $\mathrm{CH}_{3} \mathrm{COOH}$ \\
\hline & & 240 & Endo & - & 9.09 & 9.02 & Loss of $\mathrm{CH}_{3} \mathrm{COOH}$ \\
\hline & & 298 & Endo & - & - & - & Melting point \\
\hline & & 350 & - & Exo & - & - & \\
\hline & & 395 & - & Exo & - & - & \\
\hline & & 475 & - & Exo & 13.47 & 13.53 & $\begin{array}{l}\text { Decomposition process with the } \\
\text { formation of } \mathrm{CuO}\end{array}$ \\
\hline \multirow{7}{*}{ (8) } & \multirow{7}{*}{$\begin{array}{l}{\left[\left(\mathrm{H}_{2} \mathrm{~L}\right) \mathrm{Ni}\left(\mathrm{SO}_{4}\right)\left(\mathrm{H}_{2} \mathrm{O}\right)_{2}\right] \cdot \mathrm{H}_{2} \mathrm{O}} \\
\mathrm{C}_{13} \mathrm{H}_{22} \mathrm{~N}_{3} \mathrm{O}_{11} \mathrm{SNi}\end{array}$} & 92 & Endo & - & 3.69 & 3.38 & Loss of hydrated $1 \mathrm{H}_{2} \mathrm{O}$ \\
\hline & & 186 & Endo & - & 7.67 & 7.62 & Loss of coordinated $2 \mathrm{H}_{2} \mathrm{O}$ \\
\hline & & 275 & Endo & - & 22.17 & 22.03 & Loss of $\mathrm{H}_{2} \mathrm{SO}_{4}$ \\
\hline & & 314 & Endo & - & - & - & Melting point \\
\hline & & 400 & - & Exo & - & - & \\
\hline & & 420 & - & Exo & - & - & \\
\hline & & 460 & - & Exo & 22.16 & 22.88 & $\begin{array}{c}\text { Decomposition process with the } \\
\text { formation of } \mathrm{NiO}\end{array}$ \\
\hline \multirow{7}{*}{ (9) } & \multirow{7}{*}{$\begin{array}{l}{\left[(\mathrm{HL}) \mathrm{Co}(\mathrm{OAc})\left(\mathrm{H}_{2} \mathrm{O}\right)_{2}\right] \cdot 3 \mathrm{H}_{2} \mathrm{O}} \\
\mathrm{C}_{14} \mathrm{H}_{25} \mathrm{~N}_{3} \mathrm{O}_{11} \mathrm{CO}\end{array}$} & 79 & Endo & - & 11.48 & 11.01 & Loss of hydrated $3 \mathrm{H}_{2} \mathrm{O}$ \\
\hline & & 140 & Endo & - & 8.65 & 8.47 & Loss of coordinated $2 \mathrm{H}_{2} \mathrm{O}$ \\
\hline & & 170 & Endo & - & 15.52 & 15.25 & Loss of $\mathrm{CH}_{3} \mathrm{COOH}$ \\
\hline & & 325 & Endo & - & - & - & Melting point \\
\hline & & 400 & - & Exo & - & - & \\
\hline & & 430 & - & Exo & - & - & \\
\hline & & 450 & - & Exo & 13.39 & 13.55 & $\begin{array}{l}\text { Decomposition process with the } \\
\text { formation of } \mathrm{CoO}\end{array}$ \\
\hline \multirow{7}{*}{ (11) } & \multirow{7}{*}{$\begin{array}{l}{\left[(\mathrm{HL}) \mathrm{Mn}(\mathrm{OAc})\left(\mathrm{H}_{2} \mathrm{O}\right)_{2}\right] \cdot 3 \mathrm{H}_{2} \mathrm{O}} \\
\mathrm{C}_{14} \mathrm{H}_{25} \mathrm{~N}_{3} \mathrm{O}_{11} \mathrm{Mn}\end{array}$} & 90 & Endo & - & 11.58 & 11.86 & Loss of hydrated $3 \mathrm{H}_{2} \mathrm{O}$ \\
\hline & & 170 & Endo & - & 8.73 & 8.47 & Loss of coordinated $2 \mathrm{H}_{2} \mathrm{O}$ \\
\hline & & 258 & Endo & - & 15.65 & 15.69 & Loss of $\mathrm{CH}_{3} \mathrm{COOH}$ \\
\hline & & 319 & Endo & - & - & - & Melting point \\
\hline & & 390 & - & Exo & - & - & \\
\hline & & 413 & - & Exo & - & - & \multirow[b]{2}{*}{$\begin{array}{c}\text { Decomposition process with the } \\
\text { formation of } \mathrm{MnO}\end{array}$} \\
\hline & & 445 & - & Exo & 12.93 & 12.71 & \\
\hline
\end{tabular}

TABLE 6: Cytotoxic activity $\left(\mathrm{IC}_{50}\right)$ of the ligand and some metal complexes against human liver HepG2 cancer.

\begin{tabular}{lcc}
\hline Number & Compound & $\mathrm{IC}_{50}(\mu \mathrm{M})$ \\
\hline Ligand & $\mathrm{H}_{2} \mathrm{~L},(\mathbf{1})$ & $107 \pm 5.2$ \\
$(2)$ & {$\left[(\mathrm{HL}) \mathrm{Cu}(\mathrm{OAc})\left(\mathrm{H}_{2} \mathrm{O}\right)_{2}\right] \cdot \mathrm{H}_{2} \mathrm{O}$} & $6.49 \pm 1.7$ \\
$(3)$ & {$\left[(\mathrm{HL}) \mathrm{Cu}_{2}(\mathrm{OAc})_{3}\left(\mathrm{H}_{2} \mathrm{O}\right)_{5}\right]$} & $2.67 \pm 1.2$ \\
$(4)$ & {$\left[\left(\mathrm{H}_{2} \mathrm{~L}\right)_{2} \mathrm{Cu}(\mathrm{OAc})_{2}\right] \cdot 3 \mathrm{H}_{2} \mathrm{O}$} & $2.24 \pm 1.2$ \\
$(9)$ & {$\left[(\mathrm{HL}) \mathrm{Co}(\mathrm{OAc})\left(\mathrm{H}_{2} \mathrm{O}\right)_{2}\right] \cdot 3 \mathrm{H}_{2} \mathrm{O}$} & $36.80 \pm 4.0$ \\
Standard & Sorafenib $\left(\mathrm{Nexavar}_{2}\right.$ & $11.8 \pm 3.2$ \\
\hline
\end{tabular}

activity of the complexes may be attributed to the central metal atom which was explained by Tweedy's chelation theory $[55,56]$. Cytotoxicity results indicated that all tested complexes $\left(\mathrm{IC}_{50}=2.24-6.49 \mu \mathrm{M}\right)$ (except complex (9) with $\left.\mathrm{IC}_{50}=36.80 \mu \mathrm{M}\right)$ demonstrated potent cytotoxicity against HepG2 cancer cells. Copper complex (4) showed the highest

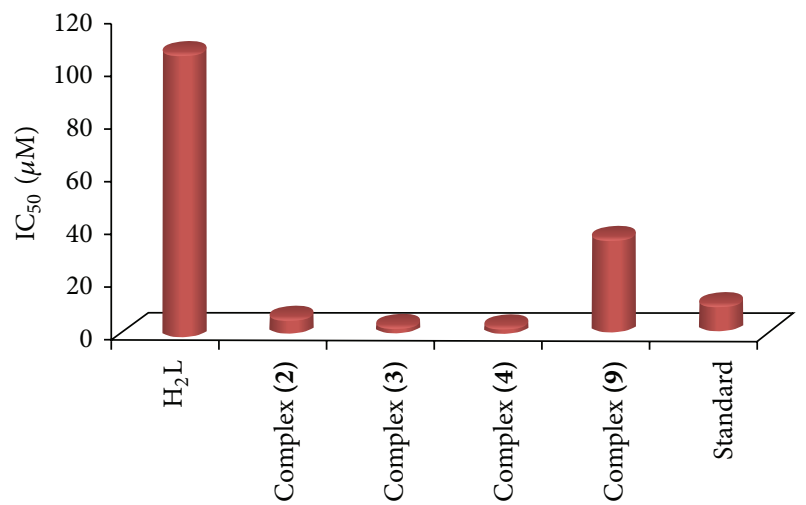

FIGURE 3: $\mathrm{IC}_{50}$ values of the ligand $\mathrm{H}_{2} \mathrm{~L}(1)$ and its metal complexes (2), (3), (4), and (9) against human liver HepG2 cancer cell.

cytotoxicity effect with $\mathrm{IC}_{50}$ value of $2.24 \mu \mathrm{M}$, followed by complex (3) with $\mathrm{IC}_{50}$ value $2.67 \mu \mathrm{M}$ and then complex 
(2) with $\mathrm{IC}_{50}$ value $6.49 \mu \mathrm{M}$. It was observed also that all complexes are more active than the free ligand. This indicated enhancing of the antitumor activity upon coordination. The enhancement of cytotoxic activity may be assigned to that the positive charge of the metal increased the acidity of coordinated ligand that bears protons, leading to stronger hydrogen bonds which enhanced the biological activity [57, 58]. It seems that changing the anion, coordination sites, and the nature of the metal ion has a pronounced effect on the biological behavior by altering the binding ability of DNA $[59,60]$. Gaetke and Chow had reported that metal has been suggested to facilitate oxidative tissue injury through a freeradical mediated pathway analogous to the Fenton reaction [61].

\section{Conclusions}

New copper(II), Nickel, cobalt(II), manganese(II), zinc(II) and cadmium(II), Mercury(II), and iron(II) metal complexes derived from $\mathrm{N}^{\prime}$-(3-(hydroxyimino)-4-oxopentan-2ylidene) salicylic hydrazide $\left(\mathrm{H}_{2} \mathrm{~L}\right)$ were synthesized. The analytical and physicochemical data confirmed the composition and structure of the newly obtained compounds. The ligand behaved as monobasic tridentate, monobasic bidentate, neutral tetradentate, and neutral tridentate. The complexes adopted distorted octahedral geometry around the metal ion. The ligand and tested complexes showed a high potential cytotoxic activity against growth human liver cancer HepG2 tumor cell lines) compared to Sorafenib (Nexavar) standard drug. All complexes were found to be more active than the free ligand. This indicates enhancing of antitumor activity upon coordination. Cupper complex (4) showed the highest cytotoxic activity with $\mathrm{IC}_{50} 2.24 \mu \mathrm{M}$ followed by complex $2.67 \mu \mathrm{M}$. These compounds are promising candidates as anticancer agents because of their high cytotoxic activity.

\section{Conflict of Interests}

The authors declare that there is no conflict of interests regarding the publication of this paper.

\section{References}

[1] M. Dörr and E. Meggers, "Metal complexes as structural templates for targeting proteins," Current Opinion in Chemical Biology, vol. 19, no. 1, pp. 76-81, 2014.

[2] G.-Y. Li, R.-L. Guan, L.-N. Ji, and H. Chao, "DNA condensation induced by metal complexes," Coordination Chemistry Reviews, vol. 281, pp. 100-113, 2014.

[3] R. W.-Y. Sun, D.-L. Ma, E. L.-M. Wong, and C.-M. Che, "Some uses of transition metal complexes as anti-cancer and anti-HIV agents," Dalton Transactions, no. 43, pp. 4884-4892, 2007.

[4] K. L. Haas and K. J. Franz, "Application of metal coordination chemistry to explore and manipulate cell biology," Chemical Reviews, vol. 109, no. 10, pp. 4921-4960, 2009.

[5] S. P. Fricker, "Metal based drugs: from serendipity to design," Dalton Transactions, no. 43, pp. 4903-4917, 2007.

[6] E. Meggers, "Targeting proteins with metal complexes," Chemical Communications, no. 9, pp. 1001-1010, 2009.
[7] R. Shchepin, D. H. M. L. P. Navarathna, R. Dumitru, S. Lippold, K. W. Nickerson, and P. H. Dussault, "Influence of heterocyclic and oxime-containing farnesol analogs on quorum sensing and pathogenicity in Candida albicans," Bioorganic \& Medicinal Chemistry, vol. 16, no. 4, pp. 1842-1848, 2008.

[8] S. Chandra, Vandana, and S. Kumar, "Synthesis, spectroscopic, anticancer, antibacterial and antifungal studies of $\mathrm{Ni}(\mathrm{II})$ and $\mathrm{Cu}$ (II) complexes with hydrazine carboxamide, 2-[3-methyl-2thienyl methylene]," Spectrochimica Acta Part A: Molecular and Biomolecular Spectroscopy, vol. 135, pp. 356-363, 2015.

[9] J.-H. Liang, W. Lv, X.-L. Li et al., "Synthesis and antibacterial activity of 9-oxime ether non-ketolides, and novel binding mode of alkylides with bacterial rRNA," Bioorganic and Medicinal Chemistry Letters, vol. 23, no. 5, pp. 1387-1393, 2013.

[10] M. I. El-Gamal, S. M. Bayomi, S. M. El-Ashry, S. A. Said, A. A.-M. Abdel-Aziz, and N. I. Abdel-Aziz, "Synthesis and antiinflammatory activity of novel (substituted)benzylidene acetone oxime ether derivatives: molecular modeling study," European Journal of Medicinal Chemistry, vol. 45, no. 4, pp. 1403$1414,2010$.

[11] P. Nirmala and M. Ramanathan, "Effect of kaempferol on lipid peroxidation and antioxidant status in 1,2-dimethyl hydrazine induced colorectal carcinoma in rats," European Journal of Pharmacology, vol. 654, no. 1, pp. 75-79, 2011.

[12] M. Özyürek, D. Akpinar, M. Bener, B. Türkkan, K. Güçlü, and R. Apak, "Novel oxime based flavanone, naringin-oxime: Synthesis, characterization and screening for antioxidant activity," Chemico-Biological Interactions, vol. 212, no. 1, pp. 40-46, 2014.

[13] R. Wang, X. Zhang, H. Song, S. Zhou, and S. Li, "Synthesis and evaluation of novel alkannin and shikonin oxime derivatives as potent antitumor agents," Bioorganic \& Medicinal Chemistry Letters, vol. 24, no. 17, pp. 4304-4307, 2014.

[14] V. M. Dilman and V. N. Anisimov, "Potentiation of antitumor effect of cyclophosphamide and hydrazine sulfate by treatment with the antidiabetic agent, 1-phenylethylbiguanide (phenformin)," Cancer Letters, vol. 7, no. 6, pp. 357-361, 1979.

[15] J. Ma, D. Chen, K. Lu et al., "Design, synthesis, and structureactivity relationships of novel benzothiazole derivatives bearing the ortho-hydroxy $\mathrm{N}$-carbamoylhydrazone moiety as potent antitumor agents," European Journal of Medicinal Chemistry, vol. 86, pp. 257-269, 2014.

[16] H. Dai, Y. Xiao, Z. Li, X. Xu, and X. Qian, "The thiazoylmethoxy modification on pyrazole oximes: synthesis and insecticidal biological evaluation beyond acaricidal activity," Chinese Chemical Letters, vol. 25, no. 7, pp. 1014-1016, 2014.

[17] A. S. El-Tabl, M. M. Abd El-Waheed, M. M. Shakdofa, and N. A. Abou El-Fadl, "Coordination compounds with biomimetic ligand: synthesis, spectroscopic characterization and antitumor activity of new metal complexes of isonicotinoylhydrazide oxime," Main Group Chemistry, vol. 12, pp. 153-168, 2013.

[18] M. Jabeen, S. Ali, S. Shahzadi, S. K. Sharma, and K. Qanungo, "Synthesis, characterization, theoretical study and biological activities of oxovanadium (IV) complexes with 2-thiophene carboxylic acid hydrazide," Journal of Photochemistry and Photobiology B: Biology, vol. 136, pp. 34-45, 2014.

[19] A. Colak, Ü. Terzi, M. Col et al., "DNA binding, antioxidant and antimicrobial activities of homo- and heteronuclear copper(II) and nickel(II) complexes with new oxime-type ligands," European Journal of Medicinal Chemistry, vol. 45, no. 11, pp. 5169$5175,2010$. 
[20] I. H. Hall, K. F. Bastow, A. E. Warren, C. R. Barnes, and G. M. Bouet, "Cytotoxicity of cobalt complexes of furan oximes in murine and human tissue-cultured cell lines," Applied Organometallic Chemistry, vol. 13, no. 11, pp. 819-828, 1999.

[21] M. F. Iskander, L. El Sayed, N. M. H. Salem, R. Werner, and W. Haase, "Metal complexes derived from hydrazoneoxime ligands: I. Synthesis, characterization and magnetochemical studies of (acylhydrazoneoxime) copper(II) complexes," Journal of Coordination Chemistry, vol. 56, no. 12, pp. 1075-1084, 2003.

[22] A. S. El-Tabl, "Novel N,N-diacetyloximo-1,3-phenylenediamine copper(II) complexes," Transition Metal Chemistry, vol. 22, no. 4, pp. 400-405, 1997.

[23] A. I. Vogel, A Textbook of Inorganic Quantitative Analysis, Longmans, Green \& Company, London, UK, 1961.

[24] B. N. Figgis and J. Lewis, Modern Coordination Chemistry, Interscience, New York, NY, USA, 1960.

[25] A. S. El-Tabl and S. A. El-Enein, "Reactivity of the new potentially binucleating ligand, 2-(acetichydrazido- $N$-methylidene$\alpha$-naphthol)-benzothiazol, towards manganese(II), nickel(II), cobalt(II), copper(II) and zinc(II) salts," Journal of Coordination Chemistry, vol. 57, no. 4, pp. 281-294, 2004.

[26] W. J. Geary, "The use of conductivity measurements in organic solvents for the characterisation of coordination compounds," Coordination Chemistry Reviews, vol. 7, no. 1, pp. 81-122, 1971.

[27] G. M. Abu El-Reash, K. M. Ibrahim, and M. M. Bekheit, "Ligational behaviour of biacetylmonoxime nicotinoyl hydrazone $\left(\mathrm{H}_{2} \mathrm{BMNH}\right)$ towards transition metal ions," Transition Metal Chemistry, vol. 15, no. 2, pp. 148-151, 1990.

[28] R. Gup and E. Giziroğlu, "Metal complexes and solvent extraction properties of isonitrosoacetophenone 2-aminobenzoylhydrazone," Spectrochimica Acta-Part A: Molecular and Biomolecular Spectroscopy, vol. 65, no. 3-4, pp. 719-726, 2006.

[29] M. F. R. Fouda, M. M. Abd-Elzaher, M. M. E. Shakdofa, F. A. El Saied, M. I. Ayad, and A. S. El Tabl, "Synthesis and characterization of transition metal complexes of $\mathrm{N}^{\prime}$ - [(1,5-dimethyl-3-oxo2-phenyl-2,3-dihydro-1H-pyrazol-4-yl)methylene] thiophene2-carbohydrazide," Transition Metal Chemistry, vol. 33, no. 2, pp. 219-228, 2008.

[30] C. Dongli, J. Handong, Z. Hongyun, C. Deji, Y. Jina, and L. Bei Jian, "Studies on acetylferrocenyl nicotinoyl and isonicotinoyl hydrazones and their coordination compounds with transition metals-II," Polyhedron, vol. 13, no. 1, pp. 57-62, 1994.

[31] A. S. El-Tabl, M. M. Abd El-Wahed, and S. E. Abd El-Razek, "Preparation, spectroscopic investigation and antiproliferative capacity of new metal complexes of (3E)-2-(hydroxyimino)N-P-Tolyl-3-(P-tolylimino) butanamide," Spectrochimica Acta. Part A: Molecular and Biomolecular Spectroscopy, vol. 105, pp. 600-611, 2013.

[32] M. M. Aly and S. M. Imam, "Characterization of Copper(II), nickel(II), cobalt(II) and palladium(II) complexes of vicinal oxime-imine ligands; induced chelate isomerism in the same molecule of the nickel(II) complex," Monatshefte für Chemie Chemical Monthly, vol. 126, no. 2, pp. 173-185, 1995.

[33] A. S. El-Tabla, R. M. El-Bahnasawy, M. M. E. Shakdofa, and A. E.-D. A. Ibrahim Hamdy, "Synthesis of novel metal complexes with isonicotinoyl hydrazide and their antibacterial activity," Journal of Chemical Research, vol. 34, no. 2, pp. 88-91, 2010.
[34] M. S. Ma, R. J. Angelici, D. Powell, and R. A. Jacobson, "Coordination chemistry of bis $(\delta$-camphorquinone dioximato)nickel(II) and -palladium(II). Reactions and structural studies of some M3Ag3 cluster complexes of camphorquinone dioxime," Inorganic Chemistry, vol. 19, no. 10, pp. 3121-3128, 1980.

[35] A. S. El-Tabl, F. A. El-Saied, W. Plass, and A. N. Al-Hakimi, "Synthesis, spectroscopic characterization and biological activity of the metal complexes of the Schiff base derived from phenylaminoacetohydrazide and dibenzoylmethane," Spectrochimica Acta-Part A: Molecular and Biomolecular Spectroscopy, vol. 71, no. 1, pp. 90-99, 2008.

[36] M. M. Aly and S. M. Imam, "Site occupancy and reactivity of nickel(II) and palladium(II) coordination compounds of vicinal oxime-imine ligands: an interpretation to the phenomenon of chelate isomerism in the same molecule," Polyhedron, vol. 13, no. 12, pp. 1907-1916, 1994.

[37] K. Nakamoto, Infrared and Raman Spectra of Inorganic and Coordination Compounds, Wiley, 1978.

[38] B. Murukan and K. Mohanan, "Synthesis, characterization, electrochemical properties and antibacterial activity of some transiton metal complexes with [(2-hydroxy-1-naphthaldehyde)-3isatin]-bishydrazone," Transition Metal Chemistry, vol. 31, no. 4, pp. 441-446, 2006.

[39] A. S. El-Tabl, F. A. El-Saied, and A. N. Al-Hakimi, "Synthesis, spectroscopic investigation and biological activity of metal complexes with ONO trifunctionalalized hydrazone ligand," Transition Metal Chemistry, vol. 32, no. 6, pp. 689-701, 2007.

[40] M. M. Aly, A. O. Baghlaf, and N. S. Ganji, "Linkage isomerism of the oximato group: the characterization of some mono- and binuclear square planar nickel(II) complexes of vicinal oximeimine ligands," Polyhedron, vol. 4, no. 7, pp. 1301-1309, 1985.

[41] A. S. El-Tabl, W. Plass, A. Buchholz, and M. M. E. Shakdofa, "Synthesis, spectroscopic investigation and biological activity of metal(II) complexes with $\mathrm{N}_{2} \mathrm{O}_{4}$ ligands," Journal of Chemical Research, no. 9, pp. 582-587, 2009.

[42] A. S. El-Tabl, "Synthesis, characterisation and antimicrobial activity of manganese(II), nickel(II), cobalt(II), copper(II) and zinc(II) complexes of a binucleating tetradentate ligand," Journal of Chemical Research, vol. 2002, pp. 529-531, 2002.

[43] B. N. Figgis, Introduction to Ligand Fields, Interscience Publishers, New York, NY, USA, 1966.

[44] M. Akbar Ali, A. H. Mirza, C. Y. Yee, H. Rahgeni, and P. V. Bernhardt, "Mixed-ligand ternary complexes of potentially pentadentate but functionally tridentate Schiff base chelates," Polyhedron, vol. 30, no. 3, pp. 542-548, 2011.

[45] G. G. Mohamed, M. M. Omar, and A. M. M. Hindy, "Synthesis, characterization and biological activity of some transition metals with Schiff base derived from 2-thiophene carboxaldehyde and aminobenzoic acid," Spectrochimica Acta Part A: Molecular and Biomolecular Spectroscopy, vol. 62, no. 4-5, pp. 1140-1150, 2005.

[46] A. B. P. Lever, "Editorial note," Coordination Chemistry Reviews, vol. 3, no. 1, p. 1, 1968.

[47] H. G. Aslan, S. Özcan, and N. Karacan, "Synthesis, characterization and antimicrobial activity of salicylaldehyde benzenesulfonylhydrazone (Hsalbsmh) and its Nickel(II), Palladium(II), Platinum(II), Copper(II), Cobalt(II) complexes," Inorganic Chemistry Communications, vol. 14, no. 9, pp. 1550-1553, 2011. 
[48] P. S. Braterman, J.-I. Song, and R. D. Peacock, "Electronic absorption spectra of the iron(II) complexes of $2,2^{\prime}$-bipyridine, 2,2'-bipyrimidine, 1,10-phenanthroline, and $2,2^{\prime}: 6^{\prime}, 2^{\prime \prime}$ terpyridine and their reduction products," Inorganic Chemistry, vol. 31, no. 4, pp. 555-559, 1992.

[49] A. N. Al-Hakimi, A. S. El-Tabl, and M. M. Shakdofa, "Coordination and biological behaviour of 2-( $p$-toluidino)- $\mathrm{N}^{\prime}$-(3-oxo-1, 3diphenylpropylidene) acetohydrazide and its metal complexes," Journal of Chemical Research, vol. 2009, no. 12, pp. 770-774, 2009.

[50] B. Hathaway, I. Procter, R. Slade, and A. Tomlinson, "The electronic properties and stereochemistry of the copper (II) ion. Part VI. Bis (bipyridyl) copper (II) complexes," Journal of the Chemical Society A: Inorganic, Physical, Theoretical, pp. 22192224, 1969.

[51] D. Kivelson and R. Neiman, "ESR line shapes in glasses of copper complexes," The Journal of Chemical Physics, vol. 35, no. 1, pp. 149-155, 1961.

[52] K. D. Karlin and J. Zubieta, Copper Coordination Chemistry: Biochemical \& Inorganic Perspectives, Adenine Press, 1983.

[53] A. Addison, "Spectroscopic and redox trends from model systems," in Copper Coordination Chemistry: Biochemical and Inorganic Perspectives, K. Karlin and J. Zubieta, Eds., pp. 109128, Adenine Press, Guilderland, Guilderland, NY, USA, 1983.

[54] N. M. Shauib, A.-Z. A. Elassar, and A. El-Dissouky, "Synthesis and spectroscopic characterization of copper(II) complexes with the polydentate chelating ligand 4, $4^{\prime}$-[1,4-phenylenedi(nitrilo)dipente-2-one," Spectrochimica Acta, Part A: Molecular and Biomolecular Spectroscopy, vol. 63, no. 3, pp. 714$722,2006$.

[55] B. Tweedy, "Plant extracts with metal ions as potential antimicrobial agents," Phytopathology, vol. 55, pp. 910-914, 1964.

[56] A. M. Ramadan, "Structural and biological aspects of copper (II) complexes with 2-methyl-3-amino-(3H)-quinazolin-4one," Journal of Inorganic Biochemistry, vol. 65, no. 3, pp. 183189, 1997.

[57] G. Feng, J. C. Mareque-Rivas, and N. H. Williams, "Comparing a mononuclear $\mathrm{Zn}$ (II) complex with hydrogen bond donors with a dinuclear $\mathrm{Zn}$ (II) complex for catalysing phosphate ester cleavage," Chemical Communications, no. 17, pp. 1845-1847, 2006.

[58] J. C. Mareque-Rivas, R. Prabaharan, and S. Parsons, "Quantifying the relative contribution of hydrogen bonding and hydrophobic environments, and coordinating groups, in the zinc(II)-water acidity by synthetic modelling chemistry," Dalton Transactions, no. 10, pp. 1648-1655, 2004.

[59] N. A. Illán-Cabeza, A. R. García-García, M. N. MorenoCarretero, J. M. Martínez-Martos, and M. J. Ramírez-Expósito, "Synthesis, characterization and antiproliferative behavior of tricarbonyl complexes of rhenium(I) with some 6-amino5-nitrosouracil derivatives: crystal structure of fac-[ReCl$\left.(\mathrm{CO})_{3}\left(\mathrm{DANU}-\mathrm{N}^{5}, \mathrm{O}^{4}\right)\right]$ (DANU = 6-amino-1,3-dimethyl-5nitrosouracil)," Journal of Inorganic Biochemistry, vol. 99, no. 8, pp. 1637-1645, 2005.

[60] G. Feng, J. C. Mareque-Rivas, R. Torres Martín de Rosales, and N. H. Williams, "A highly reactive mononuclear $\mathrm{Zn}$ (II) complex for phosphodiester cleavage," Journal of the American Chemical Society, vol. 127, no. 39, pp. 13470-13471, 2005.

[61] L. M. Gaetke and C. K. Chow, "Copper toxicity, oxidative stress, and antioxidant nutrients," Toxicology, vol. 189, no. 1-2, pp. 147163, 2003. 

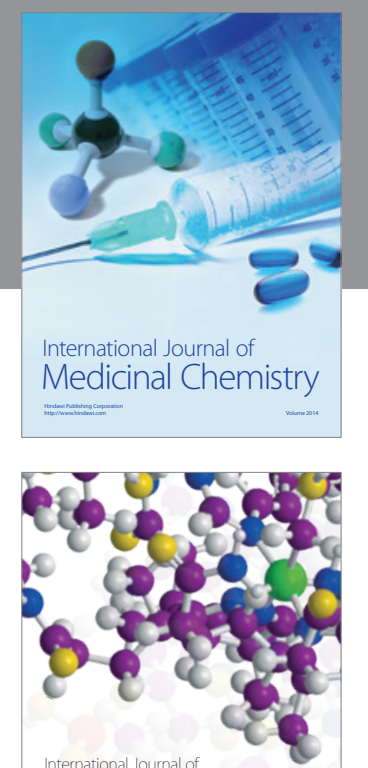

\section{Carbohydrate} Chemistry

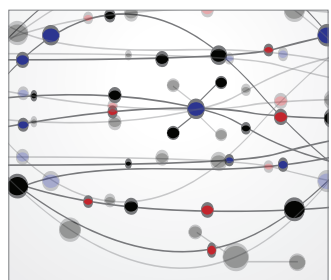

The Scientific World Journal
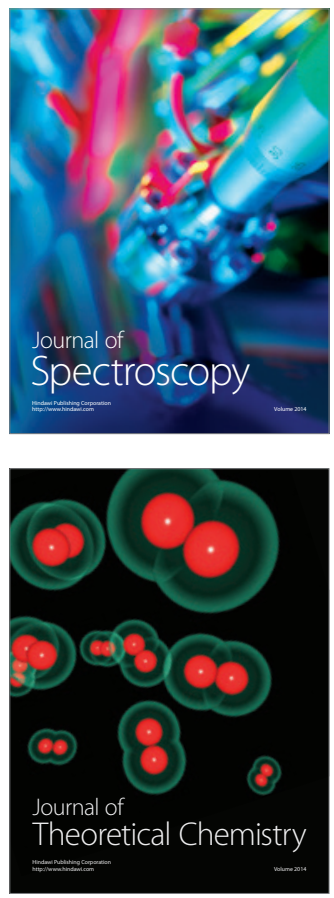
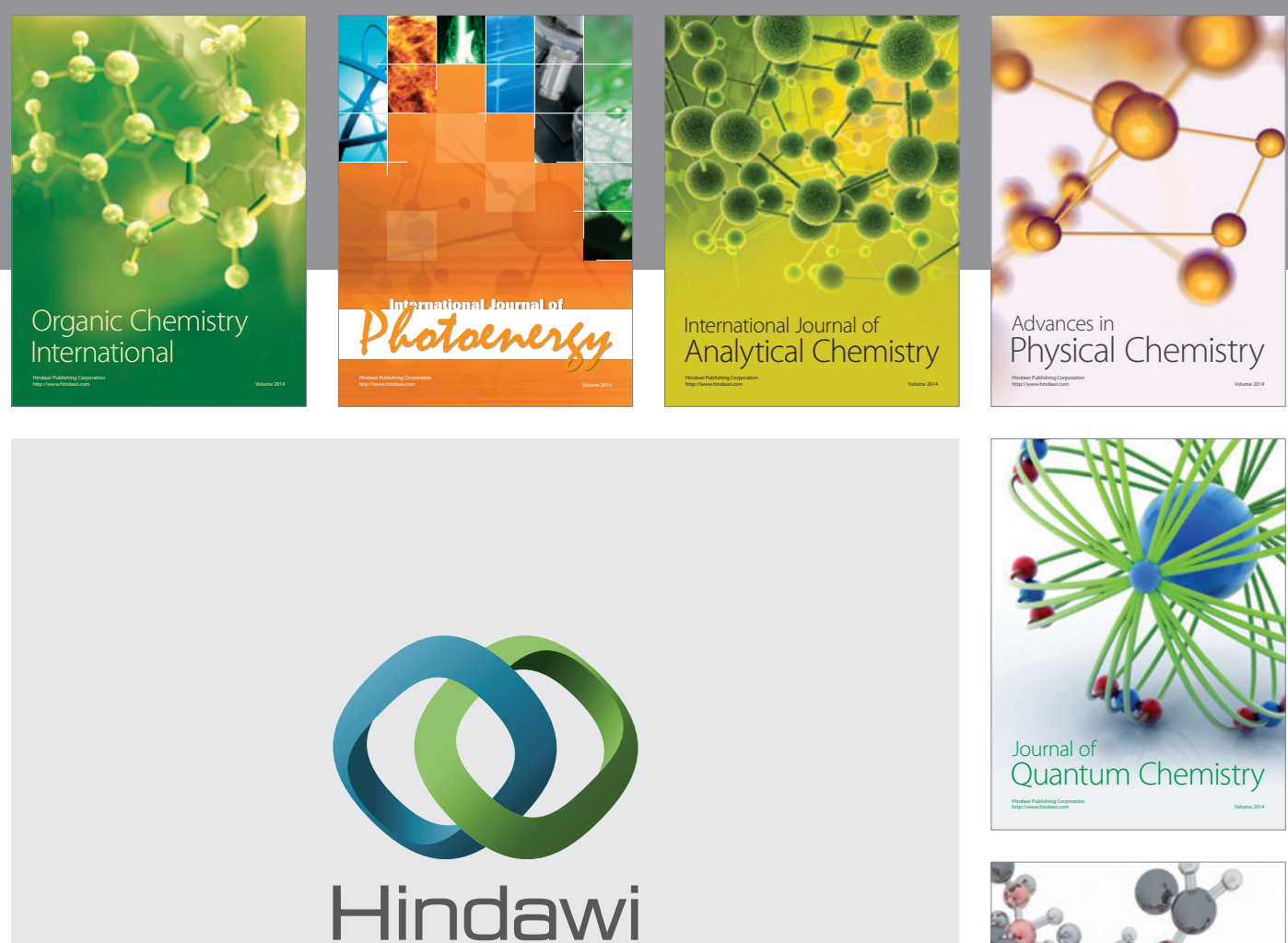

Submit your manuscripts at

http://www.hindawi.com

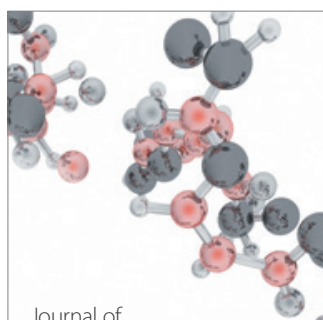

Analytical Methods

in Chemistry

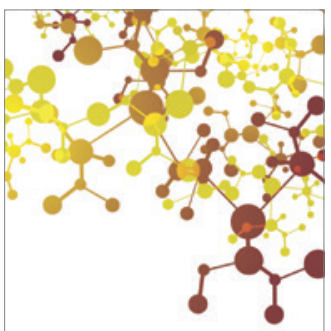

Journal of

Applied Chemistry

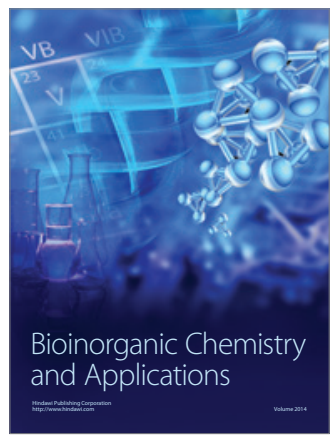

Inorganic Chemistry
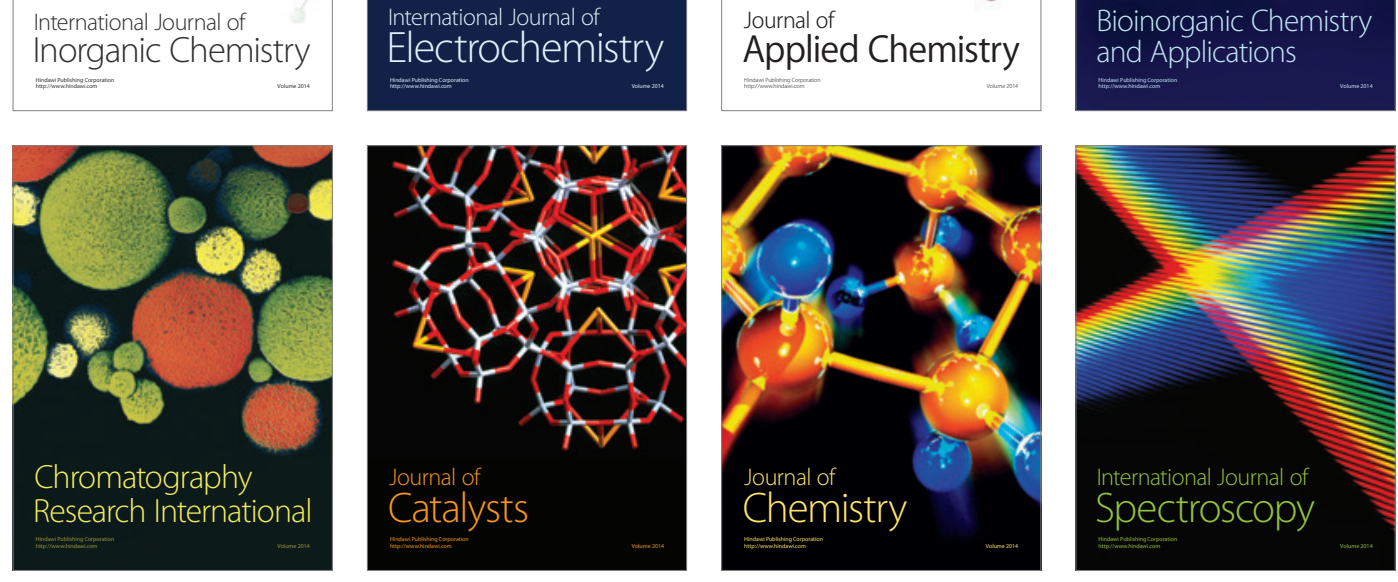